\title{
Tmetoceratidae (Ammonitina) fauna from the Gerecse Mts (Hungary)
}

\author{
Zoltán Kovács \\ Department of Pedagogy \\ Liszt Ferenc University, Budapest
}

\begin{abstract}
Taxonomic and stratigraphic problems of the family Tmetoceratidae and the genera Dumortieria, Catulloceras, Cotteswoldia, Pleydellia and Tmetoceras included in it are briefly discussed. Fifteen species of Tmetoceratidae are described and illustrated from the Upper Toarcian-Aalenian ammonite assemblages of the Gerecse Mts (NE Transdanubian Range, Hungary). The fauna described here is closely allied to the Mediterranean Province of the Mediterranean-Caucasian Realm.
\end{abstract}

Key words: Toarcian, Aalenian, Jurassic, Tmetoceratidae, Ammonitina, Gerecse Mts, Hungary

\section{Introduction}

This paper offers a detailed taxonomic treatment of the genera Dumortieria, Catulloceras, Cotteswoldia, Pleydellia and Tmetoceras from the ammonite assemblages of the Gerecse Mts, as a contribution of the comprehensive treatment of the Toarcian-Aalenian ammonite material deposited in the Natural History Museum of the Faculty of Science of Eötvös Loránd University, Budapest. The material was collected from different localities of the Gerecse Mts (Fig. 1) by the staff of the Geological Institute of Hungary between 1976 and 1982. The first taxonomic, quantitative and paleobiogeographic analyses were provided by Géczy $(1984,1985)$. The Middle Toarcian Ammonitina fauna and biostratigraphy were presented in detail by Géczy and Szente (2007), whereas the taxonomy and biostratigraphy of Upper Toarcian-Aalenian assemblages were dealt with by Kovács and Géczy (2008) and Kovács $(2009,2010)$.

\section{Address: Z. Kovács: H-1076 Budapest, Liszt Ferenc tér 8, Hungary} e-mail: kzkovacszoltan@gmail.com

Received: February 18, 2011; accepted: March 29, 2011 


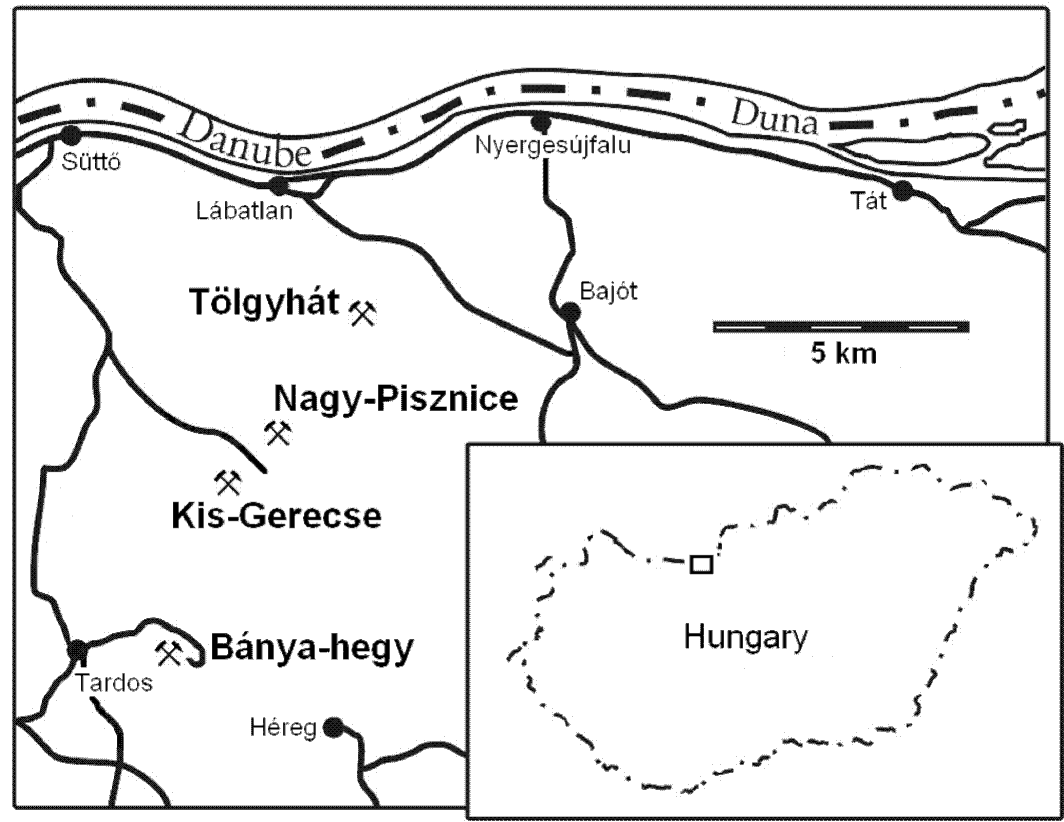

Fig. 1

Location of the Toarcian-Aalenian sections, examined in the Gerecse Mts

Research on Tmetoceratidae is significant at least in two respects. From a stratigraphic viewpoint the genera comprise index taxa for the Upper Toarcian subdivisions, and allow correlation with other regions. The diversity of the genera and the range of some species vary in different areas, so data on their distribution are important for paleobiogeographic comparisons.

Based on the abundance of Dumortieria and Catulloceras, and the scarcity of Pleydellia, the upper part of the Toarcian was first assigned to the Dumortieria levesquei Zone by Géczy (1984). The revision of the assemblage allowed a slightly more precise zonation by the introduction the Meneghinii and Aalensis Zones (Kovács and Géczy 2008), but the material did not permit further subdivision at subzonal level. Although the fauna belongs to the Mediterranean Province of the Mediterranean-Caucasian Realm, the Toarcian-Aalenian ammonite biostratigraphy proposed for the Submediterranean/NW European Province (Elmi et al. 1997) is applicable, with slight modifications. The biohorizon-level subdivision is based on the results of Géczy and Szente (2007), Kovács and Géczy (2008), and Kovács (2009), as well as on the recent re-investigation of the Lower Toarcian ammonite material of the Gerecse Mts (Fig. 2).

The lithology of the Jurassic sediments of the Gerecse Mts was studied by Császár et al. (1998). The Toarcian and Aalenian stages are characterized by the "Ammonitico Rosso marl" facies, which developed in two subfacies. Thin-bedded, 


\begin{tabular}{|c|c|c|}
\hline \multicolumn{3}{|c|}{ TOARCIAN } \\
\hline ZONE & SUBZONE & BIOHORIZON \\
\hline Pleydellia aalensis & & Cotteswoldia tenuiplicata \\
\hline Dumortieria meneghinii & & Dumortieria meneghinii \\
\hline \multirow{2}{*}{ Geczyceras speciosum } & & Crestaites szentei \\
\hline & & Geczyceras speciosum \\
\hline \multirow{3}{*}{ Grammoceras thouarsense } & Pseudogrammoceras fallaciosum & \\
\hline & Grammoceras striatulum & \\
\hline & Pseudogrammoceras bingmanni & \\
\hline \multirow{3}{*}{ Merlaites gradatus } & Merlaites alticarinatus & \\
\hline & Pseudogrammoceras subregale & \\
\hline & Merlaites clausus & \\
\hline \multirow{6}{*}{ Hildoceras bifrons } & \multirow{3}{*}{ Hildoceras bifrons } & Hildoceras semipolitum \\
\hline & & Hildoceras bifrons \\
\hline & & Hildoceras apertum \\
\hline & \multirow{3}{*}{ Hildoceras sublevisoni } & Hildoceras Iusitanicum \\
\hline & & Hildoceras tethysi \\
\hline & & Hildoceras sublevisoni \\
\hline \multirow{3}{*}{ Harpoceras serpentinum } & \multirow{2}{*}{ Harpoceras falciferum } & Orthildaites douvillei \\
\hline & & Harpoceras pseudoserpentinum \\
\hline & Harpoceras serpentinum & Hildaites striatus \\
\hline Dactylioceras tenuicostatum & & \\
\hline
\end{tabular}

Fig. 2

Ammonite zonation of the Toarcian of the Gerecse Mts, Hungary. (Zonal scheme adapted from Elmi et al. 1997 and Metodiev 2008)

red nodular marl of variable carbonate and clay content (Kisgerecse Marl Formation) is typical of the Dactylioceras tenuicostatum - Geczyceras speciosum Zones. It is overlain by the well-bedded, red, hard nodular limestone (Tölgyhát Limestone Formation) in the Upper Toarcian - Aalenian. Both subfacies are rich in ammonoid assemblages; however, the fauna consists mainly of poorly to moderately preserved internal molds.

Note: The following abbreviations are used in this paper: $\mathrm{D}-$ diameter, $\mathrm{H}-$ whorl-height, $h-H / D, W-$ whorl-width, $w-W / H, U-$ umbilical-width, $u-U / D$, RLW - ribs of the last whorl. 


\section{Systematic paleontology}

Superfamily Hammatoceratoidea Schindewolf, 1964

Family Tmetoceratidae Spath, 1936

Tmetoceratinae was introduced by Spath (1936) as a subfamily of Hildoceratidae, without diagnosis. The monogeneric taxon with genus Tmetoceras was accepted by Arkell (1957) and became widely acknowledged in the literature. Nevertheless, it was emended as family Tmetoceratidae by Schindewolf (1964), and included in the new superfamily Hammatoceratoidea. Rulleau and Mouterde (1997), in consideration of both the close morphologic and the plausible phylogenetic connection between Catulloceras and Tmetoceras, placed Tmetoceras within the reinterpreted Dumortieriinae. This subfamily (as "Dumortierae") was designated by Maubeuge (1950) for the Dumortieria Catulloceras group, but was rejected by Arkell (1957), who retained these genera and Pleydellia in the Grammoceratinae. Schindewolf (1964), based on suture constructions, accepted Dumortieriinae (Hammatoceratoidea), and also felt it reasonable to include Pleydellia, the ancestor of the genus Leioceras. Gabilly (1976) also emphasized the close relationship between Dumortieria and Pleydellia, and assigned the latter into Dumortieriinae. This classification was ignored by Donovan et al. (1981), but adopted, for instance, by Fauré and Cubaynes (1983) and Rulleau (1995). The two subfamilies were integrated by Rulleau and Mouterde (1997), and four genera: Dumortieria, Catulloceras, Pleydellia (with subgenera Cotteswoldia, Walkericeras, ?Canavarina) and Tmetoceras (successor of Catulloceras) were included in the Dumortieriinae (Graphoceratidae, Hammatoceratoidea); the subfamily was regarded as phylogenetic lineage between the latter family and the Hammatoceratidae. After the study of Rulleau et al. (2001) this scheme met with a wide acceptance in the literature, but was slightly modified by Fauré (2002) at generic level (see below). On the other hand, Dumortieria, Catulloceras, Cotteswoldia and Pleydellia were henceforward placed in the Grammoceratinae (Hildoceratoidea), for instance by Ohmert (1993) and Schulbert (2001). Dumortieria, Catulloceras and Tmetoceras were recently grouped into the revised Tmetoceratidae Spath (Hammatoceratoidea) by Venturi and Ferri (2001), Venturi and Bilotta (2008) and Venturi et al. (2010); Pleydellia, however, was classified among the Grammoceratinae. The close relationship between the above-mentioned genera seems unquestionable; moreover, the arrangements of Schindewolf (1964), Rulleau and Mouterde (1997), and Venturi and Ferri (2001) are properly reconcilable for phylogenetic and morphological reasons. However, the marked differences between the ventral parts of Tmetoceras and the other taxa must be emphasized by distinguishing two subfamilies within family Tmetoceratidae. The following genera are included:

I. Subfamily Dumortieriinae Maubeuge, 1950: Dumortieria Haug, 1885; Catulloceras Gemmellaro, 1886; Cotteswoldia Buckman, 1902; Pleydellia Buckman, 1899 
II. Subfamily Tmetoceratinae Spath, 1936: Tmetoceras Buckman, 1892

The distribution of Late Toarcian subfamilies of Ammonitina within the Gerecse material is given in Kovács and Géczy (2008). Dumortieriinae culminated in the Meneghinii Zone with 52\% of the fauna, and reached $34 \%$ in the Aalensis Zone, whereas Tmetoceras formed only $1.3 \%$ in the Aalenian. The ranges of the species recorded here from the Gerecse Mts are shown in Fig. 3.

\section{Subfamily Dumortieriinae Maubeuge, 1950 \\ Genus Dumortieria Haug, 1885}

Type species: Ammonites levesquei D'Orbigny, 1844; designated by Haug (1885).

Diagnosis: Evolute, compressed form with wide and shallow umbilicus. Slightly convex flank, rounded venter, weakly developed keel, suboval section. Strong, simple, straight to sigmoid, non-tuberculate ribs. Moderately developed sutureline with long and wide L lobe, broad ES and broad, asymmetrical LS.

Remarks: Detailed analyses of the genus were recently provided by Rulleau $(1995,2007)$, Metodiev (1997), Rulleau and Mouterde (1997), Rulleau et al. (2001), Venturi and Ferri (2001), Schulbert (2001), Fauré (2002), Pallini et al. (2005) and Venturi et al. (2010). Dumortieria is closely allied to Catulloceras; however, it differs in at least three ways: the venter is narrower and rounded without ventral grooves; the whorl-section is suboval and both the type of the ornamentation and the shape of the section vary during ontogeny. Dumortieria is characterized by sexual dimorphism: D. tabulata Buckman, D. explanata Buckman, Paradumortieria elmii Seyed-Emami etc. are regarded as microconch forms.

In Europe the paleogeographic range of the genus differs in the NW European and Mediterranean Provinces. The dominance of D. meneghinii (Zittel in Haug), D. evolutissima Prinz and D. latumbilicata Géczy is characteristic in the Tethyan localities. Some species are common in both provinces: e.g. D. levesquei (D'Orbigny), D. pseudoradiosa (Branco), D. striatulocostata (Quenstedt), D. rhodanica Haug, D. taramellii (Fucini), D. insignisimilis (Brauns), while the more involute, compressed, fine-ribbed forms are typical of the Pseudoradiosa Subzone of the NW European areas: for instance, D. radians (Reinecke), D. moorei (Lycett), D. brancoi Buckman, D. multicostata Buckman are rare or absent from the Italian, Southern Spanish, Greek, Algerian and Hungarian assemblages. The Dumortieria material of Morocco seems to be mixed; it is closely allied to both provinces (Benshili 1989; El Hammichi et al. 2009). In the MediterraneanCaucasian Realm the Bulgarian (Metodiev 1997, 2008), Iranian (Seyed-Emami et al. 2005, 2008), and Caucasian (Rostovtsev 1965; Nutsubidze 1966; Topchishvili et al. 2006) Dumortieria assemblages are similar to those of the NW European Province.

The origin of Dumortieria seems uncertain: since its suture construction can be interpreted as a simplified variation of the hammatoceratid style of lobe, Dumortieria is thought to derive from the Hammatoceratinae in the late Speciosum/Dispansum Zone. The subserpenticone coiling and the sculpture 


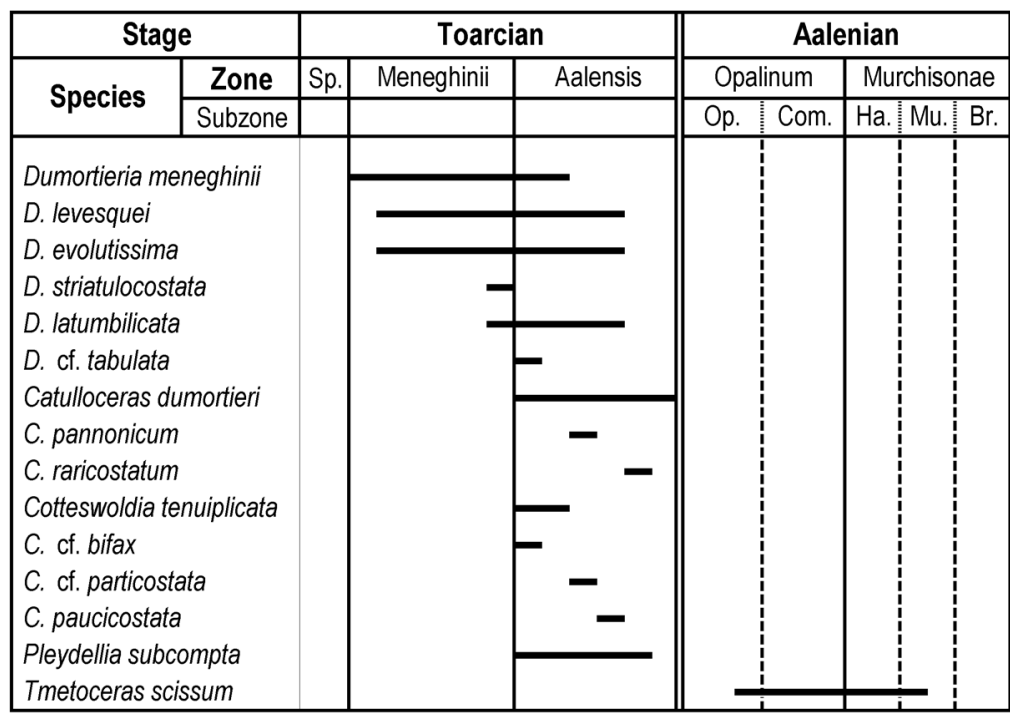

Fig. 3

Stratigraphic distribution of the Tmetoceratidae of the Gerecse Mts. (Sp. Speciosum, Op. - Opalinum, Com. - Comptum, Ha. - Haugi, Mu. - Murchisonae, $\mathrm{Br}$ - Bradfordensis)

characterized by simple ribs might have originated from Crestaites. The acme of Dumortieria was typical of the Meneghinii/Pseudoradiosa Zone. The genus is regarded as the ancestor of the genera Catulloceras, Cotteswoldia and Pleydellia.

The "classic" Gerecse ammonite assemblage contains 143 Dumortieria specimens of which 43 are determined at species level. Six species are represented: $D$. levesquei, D. meneghinii, D. evolutissima, D. latumbilicata, D. striatulocostata and D. cf. tabulata. The diversity of the Bakonycsernye material was similar according to the recent classification; seven species were recorded (D. meneghinii, D. latumbilicata, D. taramellii, D. evolutissima, D. insignisimilis, D. striatulocostata and D. cf. rhodanica) by Géczy (1967), while two species are known from the Úrkút (D. meneghinii and D. cf. rhodanica) and the Szentgál sections (D. meneghinii, D. evolutissima) (Bakony Mts) (Géczy 1968, 1975). The Mediterranean forms dominate the Dumortieria faunas of the Transdanubian Range.

Distribution: Occurs worldwide in the Upper Toarcian.

\section{Dumortieria levesquei (d'Orbigny, 1844)}

(Plate 2, Fig. 1; Plate 5, Fig. 5)

1844 Ammonites levesquei - d'Orbigny, p. 260, Pl. 60, Figs 1-4

1966 Dumortieria levesquei d'Orbigny - Nutsubidze, p. 107, Pl. 24, Fig. 1 (cum syn.)

1978 Dumortieria cfr. levesquei (d'Orbigny) - Dezi and Ridolfi, p. 17, Figs 2-3

1985 Dumortieria levesquei (d'Orbigny) - Seyed-Emami and Nabavi, p. 248, Fig. 13

1997 Dumortieria levesquei (d'Orbigny) - Metodiev, p. 20, Pl. 4, Fig. 2 (cum syn.) 
2001 Dumortieria levesquei (d'Orbigny) - Schulbert, p. 61, Text-fig. 4.3/g; Pl. 5, Figs 1-3, 10 (cum syn.) 2002 Dumortieria levesquei (d'Orbigny) - Fauré, p. 728, Pl. 22, Fig. 2

2004 Dumortieria cf. levesquei (d'Orbigny) - Myczynski, p. 56, Fig. 23/2, 6

2007 Dumortieria levesquei (d'Orbigny) - Rulleau, p. 90, Pl. 49, Fig. 3

2010 Dumortieria levesquei (d'Orbigny) - Arp, p. 38, Pl. 1, Figs 2-3 (cum syn.)

Material: Five poorly preserved internal molds (03.2011-07.2011).

$\begin{array}{lllllllll}\text { Measurements: } & \mathrm{D} & \mathrm{H} & \mathrm{h} & \mathrm{W} & \mathrm{w} & \mathrm{U} & \mathrm{u} & \text { RLW } \\ 03.2011 & 77 & 20 & 26 \% & 13 & 65 \% & 40 & 52 \% & 50(?) \\ 04.2011 & 74 & 20 & 27 \% & 14 & 70 \% & 38 & 51.3 \% & 50\end{array}$

Description: Evolute form, shallow umbilicus, convex flank, narrow, rounded, carinate venter. Suboval whorl-section with maximum width at mid-height. The body chamber is three-quarters whorl in length. Oblique, projected peristome, preceded by a wide, deep constriction. Strong, straight, rectiradiate, simple ribs, rise from the umbilicus, bend forward on the ventrolateral part, fade away near the keel. Suture-line: narrow E, slightly longer, wide L, short, oblique U lobes; wide ES, wide, asymmetrically divided LS.

Remarks: The lectotype of $D$. levesquei was designated and figured by Gabilly and Mouterde (1994: 58, Pl. 36, Fig. 3; re-illustrated by Elmi et al. 1997, Pl. 11, Figs 9-10). Both Gerecse specimens agree well with the type. The species differs from both $D$. meneghinii and D. latumbilicata in slightly more involute coiling (U/D: $46-52 \%)$ and coarser, widely spaced ribs.

Distribution: Pseudoradiosa/Meneghinii Zone: Europe, Morocco, Caucasus, Iran. Yakounensis Zone: North America. Gerecse Mts: Meneghinii Zone: Kis-Gerecse and Tölgyhát (A) sections, Meneghinii - Aalensis Zones: Nagy-Pisznice section.

\section{Dumortieria meneghinii (Zittel in Haug, 1887)}

(Plate 1, Figs 1-2; Plate 2, Fig. 4)

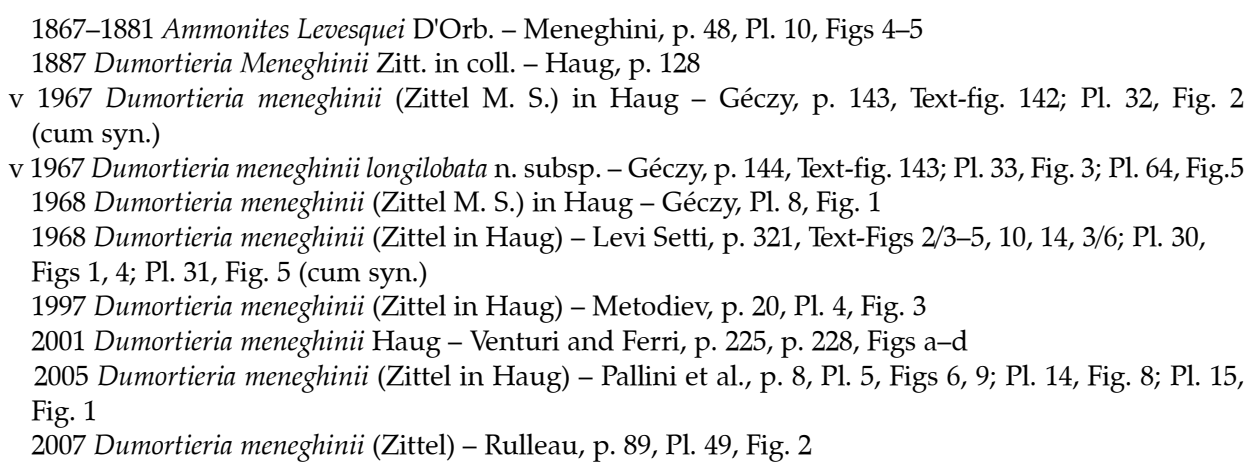

Material: 23 internal molds in different states of preservation (08.2011-30.2011). 


$\begin{array}{cllllllll}\text { Measurements } & \mathrm{D} & \mathrm{H} & \mathrm{h} & \mathrm{W} & \mathrm{w} & \mathrm{U} & \mathrm{u} & \mathrm{RLW} \\ 08.2011 & 114 & 26 & 22.8 \% & 16 & 61.5 \% & 66 & 57.8 \% & 50(?) \\ 09.2011 & 112 & 26 & 23.2 \% & 19 & 73 \% & 64 & 57 \% & 63 \\ 10.2011 & 85 & 20 & 23.5 \% & 14 & 70 \% & 47 & 55.3 \% & 53 \\ 11.2011 & 67 & 17 & 25.3 \% & 12 & 70.5 \% & 36 & 53.7 \% & 61\end{array}$

Description: Evolute, compressed form, suboval whorl-section, wide, shallow umbilicus, low, rounded margin. Slightly convex flank, narrow, rounded, carinate venter, no ventral sulci. The body chamber is more than three-quarters whorl in length. Projected peristome, preceded by a wide constriction. Strong, simple, slightly curved, prorsiradiate ribs, bend forward and fade away on the venter without reaching the keel. Two narrow, deep constrictions on the last, and 2-3 on the inner whorls. Suture-line: wide E, slightly longer L, short, oblique U lobes; wide ES, wide, asymmetrically divided LS.

Remarks: The Gerecse specimens are close to the lectotype (Meneghini, 1867-1881, Pl. 10, Fig. 4, designated and re-illustrated by Pinna 1969, Pl. 2, Fig. 7). The specimens shown in the literature show slight variability in whorl-width, ribdensity, length of lateral lobe, and breadth of lateral saddle (e.g. D. meneghinii, Pinna 1968, Text-fig. 6; D. meneghinii longilobata, Géczy 1967, Pl. 33, Fig. 3).

Distribution: Meneghinii/Pseudoradiosa Zone: Italy, Morocco, Tunisia, Algeria, Portugal, Greece, France. Levesquei Zone: Southern Spain, Austria, Bulgaria. Upper Toarcian: Bakony Mts (Hungary). Gerecse Mts: Meneghinii - lower Aalensis Zones.

\section{Dumortieria evolutissima Prinz, 1904}

(Plate 3, Fig. 1; Plate 7, Fig. 1)

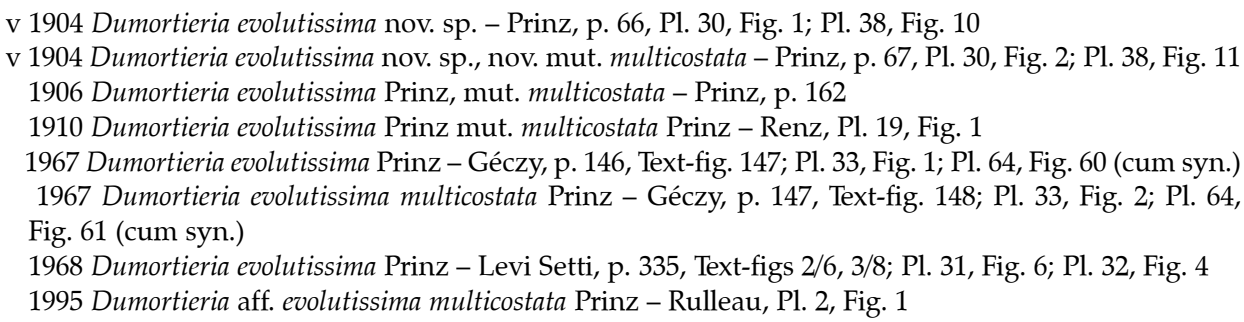

Material: Five moderately preserved internal molds, and 6 fragmentary specimens (31.2011-41.2011).

$\begin{array}{lllllllll}\text { Measurements } & \mathrm{D} & \mathrm{H} & \mathrm{h} & \mathrm{W} & \mathrm{w} & \mathrm{U} & \mathrm{u} & \mathrm{RLW} \\ 31.2011 & 134 & 30 & 22.3 \% & 24 & 80 \% & 79 & 59 \% & 62 \\ 32.2011 & 94 & 20 & 21 \% & 16 & 80 \% & 58 & 62 \% & ? \\ 33.2011 & 80 & 18 & 21.2 \% & 16 & 88.8 \% & 48 & 60 \% & 66\end{array}$

Description: Subserpenticone form, wide, shallow umbilicus, convex flank, broad, rounded, carinate venter. Subcircular whorl-section on the inner, wide-oval on 
the external whorls with maximum width under the mid-height. The body chamber is about three-quarters whorl in length. Projected peristome, preceded by a wide and shallow constriction; and 3 deep, narrow constrictions on the last whorl. Well-developed, single, rectiradiate, straight to slightly curved ribs. Three to four constrictions on the inner whorls. Suture-line: short, narrow E, long, moderately wide L, short, oblique U lobes; broad ES, broad, asymmetrical LS.

Remarks: D. evolutissima multicostata was regarded as synonym of D. evolutissima by Levi Setti $(1968,338$ p.). This arrangement is confirmed here by the reinvestigation of the type specimens (deposited in the Geological Institute of Hungary). The type of $D$. evolutissima is a poorly preserved internal mold with dissolved surface; the ribs of the innermost whorls are invisible. The styles of coiling show only slight differences; the numbers of the ribs are the same on both external whorls. Most Gerecse specimens agree well with the type of $D$. evolutissima multicostata (Prinz 1904, Pl. 30, Fig. 2, re-illustrated by Géczy 1967, Pl. 33, Fig. 2), and the specimens shown by Renz (1910, Pl. 19, Fig. 1) and Rulleau (1995, Pl. 2, Fig. 1). The species differs from D. meneghinii in subserpenticone coiling and wider whorls. In the literature the U/D proportions of D. meneghinii are $53-58.5 \%, 67.5 \%$ for the type of D. evolutissima, $62.5 \%$ for D. evolutissima multicostata, and $56-63 \%$ for the specimens illustrated by Renz (1.c.), Levi Setti (l.c.), and Rulleau (l.c.). The D. evolutissima specimens of Levi Setti with low W/H data $(61-80 \%)$ markedly differ from the types $(\mathrm{W} / \mathrm{H}: 90 \%)$. Considering the variability of the whorl-thickness, the presence of wide, suboval-subquadrate sections with $80-90 \% \mathrm{~W} / \mathrm{H}$ proportion is recognized here as a specific morphological feature.

Distribution: Meneghinii/Pseudoradiosa Zone: Italy, France, Morocco, Algeria. Levesquei Zone: Austria, Southern Spain. Upper Toarcian: Greece, Hungary (Bakony Mts). Gerecse Mts: Meneghinii - lower Aalensis Zones.

Dumortieria latumbilicata Géczy, 1967

(Plate 2, Fig. 3)

v 1904 Dumortieria Levesquei d'Orbigny - Prinz, p. 67, Pl. 24, Fig. 1

1967 Dumortieria levesquei latumbilicata n. subsp. - Géczy, p. 146, Text-fig. 146; Pl. 32, Figs 1, 6; Pl. 64, Figs 58-59

1968 Dumortieria latumbilicata Géczy - Levi Setti, p. 331, Text-figs 2/11-12, 3/7; P1. 32, Figs 1-2

1974 Dumortieria cf. latumbilicata Géczy - Elmi et al., Text-fig. 17/32; Pl. 5, Fig. 5

1997 Dumortieria latumbilicata Géczy - Rulleau and Mouterde, Pl. 1, Fig. 2

2002 Dumortieria latumbilicata Géczy - Fauré, p. 728, Pl. 22, Fig. 7

2005 Dumortieria latumbilicata Géczy - Pallini et al., p. 8, Pl. 5, Figs 7, 10; Pl. 15, Figs 2-3

2007 Dumortieria latumbilicata Géczy - Rulleau, Pl. 48, Fig. 5

Material: One poorly preserved internal mold, and one fragmentary specimen.

$\begin{array}{lllllllll}\text { Measurements: } & \mathrm{D} & \mathrm{H} & \mathrm{h} & \mathrm{W} & \mathrm{w} & \mathrm{U} & \mathrm{u} & \mathrm{RLW} \\ 42.2011 & 93 & 24 & 25.8 \% & 20 & 83.3 \% & 51 & 54.8 \% & 53 \\ 43.2011 & 93 & 25 & 26.8 \% & 22 & 88 \% & 51 & 54.8 \%\end{array}$


Description: Evolute form, shallow umbilicus, rounded umbilical wall and margin, slightly convex flank. Broad, low, rounded, carinate venter, weakly developed keel. Wide-oval section with maximum width under the mid-height. The body chamber is somewhat more than a half whorl in length. Projected peristome, preceded by a wide and deep constriction; three narrow constrictions on the last whorl. Strong, straight, simple ribs, bend forward on the ventrolateral part and fade away on the venter. The suture-line cannot be traced in all details, but is typical of Dumortieria.

Remarks: The Gerecse specimens are close to the types (Géczy 1967, Pl. 32, Figs 1, 6), and the specimens illustrated by Levi Setti (1968, Pl. 32, Fig. 1) and Rulleau (2007, Pl. 48, Fig. 5). The species differs from D. levesquei in more evolute coiling, and from $D$. meneghinii in much wider section and stronger ribs. $D$. insignisimilis is a robust form with more involute coiling and subcircular section.

Distribution: Meneghinii/Pseudoradiosa/Reynesi Zone: Italy, Southern Spain, France, Portugal, Morocco, Tunisia, Algeria. Upper Toarcian: Bakonycsernye (Hungary). Gerecse Mts: upper Meneghinii - Aalensis Zones.

Dumortieria striatulocostata (Quenstedt, 1885)

(Plate 4, Fig. 1)

1885 Ammonites striatulo-costatus - Quenstedt, p. 413, Pl. 52, Fig. 7 (non Figs 8-10)

1966 Dumortieria striatulo-costata Quenstedt - Nutsubidze, p. 112, Pl. 24, Fig. 6(!); Pl. 25, Fig. (cum syn.)

v 1967 Dumortieria striatulocostata (Quenstedt) - Géczy, p. 141, Text-fig. 139; Pl. 31, Fig. 4; Pl. 64, Fig. 53 2001 Dumortieria striatulocostata (Quenstedt) - Schulbert, p. 74, Text-fig. 4.3/g; Pl. 8, Fig. 1 (cum syn.) 2002 Dumortieria striatulocostata (Quenstedt) - Fauré, p. 729, Pl. 22, Fig. 6

2005 Dumortieria striatulocostata (Quenstedt) - Seyed-Emami et al., p. 359, Fig. 5/G

2007 Dumortieria striatulocostata (Quenstedt) - Rulleau, Pl. 50, Fig. 4

2010 Dumortieria striatulocostata (Quenstedt) - Arp, p. 39, Pl. 1, Fig. 1

Material: One moderately preserved internal mold.

$\begin{array}{lllllllll}\text { Measurements: } & \mathrm{D} & \mathrm{H} & \mathrm{h} & \mathrm{W} & \mathrm{w} & \mathrm{U} & \mathrm{u}\end{array}$

$\begin{array}{llllllll}44.2011 & 94 & 30 & 32 \% & 16 & 53.3 \% & 41 & 43.6 \%\end{array}$

Description: Evolute, compressed form, shallow umbilicus, slightly convex flank, low, narrow, carinate venter. Narrow suboval whorl-section with maximum width above the margin. No whole body chamber preserved. Almost straight, prorsiradiate, simple ribs on the inner whorls, slightly denser and sigmoid ribs on the external whorl. 47 primaries with 5 ventrolateral intercalatories on the last whorl. Suture-line: narrow E, long, narrow L, short, oblique U lobes; wide ES, broad, asymmetrically divided LS.

Remarks: The Gerecse specimen is close to the type (Quenstedt, 1885, Pl. 52, Fig. 7, re-illustrated by Schlegelmilch 1976, Pl. 50, Fig. 4) in morphology, but differs by bearing slightly denser and non-rectiradiate ribs on the penultimate whorl. This 
style of ribbing can be interpreted as a transitional stage between two nearly related forms: D. striatulocostata and D. pseudoradiosa.

Distribution: Levesquei Zone: Germany, Austria. Pseudoradiosa Zone: France, Northern Spain, Bulgaria, Caucasus. Upper Toarcian: England, Italy, Switzerland, Bulgaria, Bosnia-Herzegovina, Hungary (Bakonycsernye), North Africa. Gerecse Mts: upper Meneghinii Zone: Kis-Gerecse section.

\section{Dumortieria cf. tabulata Buckman, 1904}

(Plate 2, Fig. 2)

1904 Dumortieria tabulata - Buckman, p. S.185, Pl. 22, Figs 25-27

1965 Dumortieria tabulata Buckman - Rostovtsev, p. 82, Pl. 13, Fig. 3 (cum syn.)

1995 Dumortieria tabulata (Buckman) - Rulleau, Pl. 6, Figs 6-7

2001 Dumortieria tabulata Buckman - Schulbert, p. 73, Pl. 9, Fig. 5

2004 Dumortieria cf. tabulata Buckman - Myczynski, p. 60, Fig. 25/1-2

2006 Dumortieria tabulata Buckman - Topchishvili et al., Pl. 20, Fig. 5

2007 Dumortieria aff. tabulata Buckman - Rulleau, p. 90, Pl. 51, Fig. 4

Material: One fragmentary internal mold (45.2011: D: appr. 28).

Description: Small, moderately evolute form, shallow umbilicus, slightly convex flank. The ventral part is damaged. Simple, strong, straight, rectiradiate ribs, bend forward around the shoulder. Slightly wider intercosta than the rib-width. The suture-line cannot be observed in all details, but is typical of Dumortieria.

Remarks: The Gerecse specimen resembles the type (Buckman 1904, Pl. 22, Fig. 26) in morphology, but the poor preservation does not allow examination of the exact arrangement. The species is closely allied with D. explanata Buckman in size and morphology, but differs in wider whorls, lower venter, and less sigmoid ribs on the body chamber. Both species are considered as Dumortieria microconchs.

Distribution: Pseudoradiosa - Aalensis Zones: England, France, Germany, Poland, Bulgaria, Caucasus, Iran. Gerecse Mts: lowermost Aalensis Zone: Kis-Gerecse section.

\section{Genus Catulloceras Gemmellaro, 1886}

Type species: Ammonites Dumortieri Thiolliere in Dumortier, 1874; designated by Buckman (1905).

Diagnosis: Evolute coiling, wide and moderately deep umbilicus with high and rounded margin. Convex flanks, low, broad and carinate venter with two shallow grooves. Subcircular to subquadrate whorl-section. Strong, simple ribs. Constrictions can appear. Moderately developed suture-line similar to that of Dumortieria.

Remarks: The genus was recently discussed by Rulleau (1995, 2007), Schweigert (1996), Rulleau and Mouterde (1997), Rulleau et al. (2001), Schulbert (2001), Venturi and Ferri (2001), Goy (2002) and Venturi et al. (2010). Catulloceras differs 
from Dumortieria in appearance of the ventral region and whorl-section, as well as in progressive development of the whorls. The genus is one of the derivatives of Dumortieria, appeared in the late Meneghinii/Pseudoradiosa Zone, flourished during the Aalensis Zone, and disappeared in the early Opalinum Subzone. It has been regarded as the ancestor of the genus Tmetoceras.

The examined sections yielded eight Catulloceras specimens which represent three species: C. dumortieri (Thiolliere in Dumortier), C. pannonicum (Géczy) and C. raricostatum (Géczy). A single C. (?) strictum (Prinz) was recorded from NagyPisznice Hill by Prinz (1906); unfortunately, the specimen has been lost. C. dumortieri, C. strictum, C. pannonicum, C. raricostatum, C. perroudi (Dumortier et Fontannes) are known from Bakonycsernye, C. pannonicum from Úrkút and $C$. raricostatum from Szentgál (Géczy 1967, 1968, 1975).

Distribution: Upper Toarcian: Europe, North Africa, Madagascar, Thailand, Pamir Mts, South and North America. Upper Toarcian - lowermost Aalenian: Italy, Portugal, Germany.

Catulloceras dumortieri (Thiolliere in Dumortier, 1874)

(Plate 4, Fig. 3)

1874 Ammonites Dumortieri (Thiolliere) - Dumortier, p. 269, Pl. 57, Figs 3-4

v 1967 Dumortieria dumortieri (Thiolliere in Dumortier) - Géczy, p. 137, Text-fig. 134; Pl. 30, Fig. 8; Pl. 64, Fig. 48 (cum syn.)

1968 Dumortieria dumortieri (Thiolliere in Dumortier) - Levi Setti, p. 329, Text-figs 2/9, 3/10; Pl. 30, Fig. 3; Pl. 31, Fig. 1 (cum syn.)

1997 Catulloceras dumortieri (Thiolliere in Dumortier) - Rulleau and Mouterde, Pl. 1, Fig. 5; Pl. 2,

Figs 1-6

2001 Catulloceras dumortieri (Thiolliere) - Schulbert, p. 60, Pl. 6, Fig. 1 (cum syn.)

2002 Catulloceras dumortieri (Thiolliere in Dumortier) - Goy, p. 154, Fig. 96

2007 Catulloceras dumortieri (Thiolliere in Dumortier) - Rulleau, p. 90, Text-fig. 24/7; Pl. 52, Fig. 6

2007 Catulloceras gr. dumortieri (Thiolliere in Dumortier) - Elmi et al., Pl. 2, Fig. 4

v 2007 Catulloceras dumortieri (Thiolliere in Dumortier) - Galácz et al., p. 346, Fig. 3/2

2009 Catulloceras dumortieri (Thiolliere in Dumortier) - El Hammichi et al., Pl. 2, Fig. 6

Material: One moderately preserved internal mold, and four fragmentary specimens (46.2011-50.2011).

$\begin{array}{lllllllll}\text { Measurements: } & \mathrm{D} & \mathrm{H} & \mathrm{h} & \mathrm{W} & \mathrm{w} & \mathrm{U} & \mathrm{u} & \text { RLW } \\ 46.2011 & 68 & 20 & 29.4 \% & 16 & 80 \% & 36 & 53 \% & 57\end{array}$

Description: Evolute form, wide, gradually deepening umbilicus. Vertical umbilical wall, rounded margin. Slightly convex, parallel flanks; low, rounded venter, low keel, bordered by narrow grooves. Wide subrectangular whorlsection. No preserved body chamber. Well-developed, simple, straight, slightly prorsiradiate ribs; 3 deep constrictions on each whorl. Suture-line: wide E, slightly shorter L, short, oblique U lobes; wide ES, wide, asymmetrically divided LS. 
Remarks: The Gerecse specimens agree with the type (Dumortier, 1874, Pl. 57, Figs 3-4, re-illustrated by Rulleau 1995, Pl. 4, Figs 1-2, and Elmi et al. 1997, Pl. 11, Figs 13-14). The species is close to C. pannonicum (Géczy) in style of coiling, but differs by its narrower whorls. It also differs from $C$. raricostatum in having denser ribs. Distribution: Meneghinii - Aalensis Zones: Algeria. Aalensis Zone: Italy, France, Spain, Austria, Morocco. Levesquei - Opalinum Zones: Portugal, Germany. Yakounensis Zone: Canada. Upper Toarcian: Greece, England, Austria, Poland, Madagascar, Bakonycsernye (Hungary). Gerecse Mts: Aalensis Zone.

\section{Catulloceras pannonicum (Géczy, 1967)}

(Plate 3, Fig. 2)

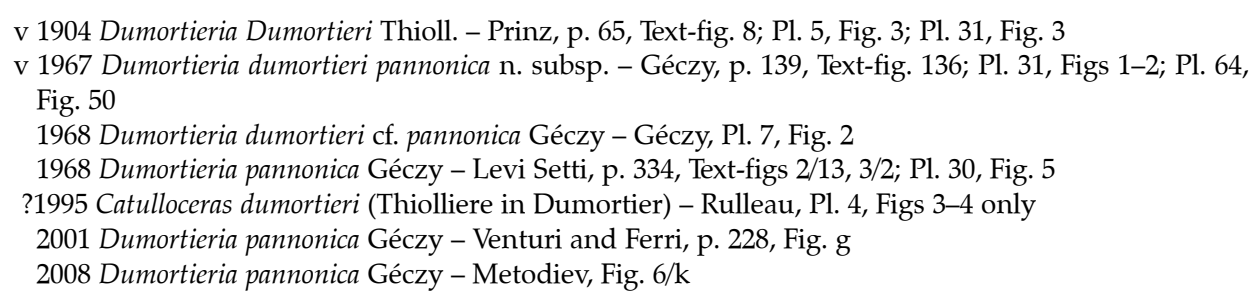

Material: One moderately preserved internal mold, and one fragmentary specimen (51.2011-52.2011).

$\begin{array}{lllllllll}\text { Measurements: } & \mathrm{D} & \mathrm{H} & \mathrm{h} & \mathrm{W} & \mathrm{w} & \mathrm{U} & \mathrm{u} & \mathrm{RLW} \\ 51.2011 & 66 & 17 & 25.7 \% & 18 & 105.8 \% & 34 & 51.5 \% & 47\end{array}$

Description: Evolute, robust form, wide, gradually deepening umbilicus. Rounded umbilical wall and margin, convex flank, broad, low, rounded venter, sharp keel, bordered by narrow sulci. Subcircular whorl-section with maximum width under the mid-flank. The preserved body chamber is a quarter whorl in length. Strong, simple, slightly curved, prorsiradiate ribs; three deep constrictions on each whorl. More widely spaced ribs on the body chamber Suture-line: very close to that of $C$. dumortieri.

Remarks: The Gerecse specimens agree well with the holotype (Géczy 1967, Pl. 31 , Figs 1-2), as well as with the specimens shown by Levi Setti (1968, Pl. 30, Fig. 5) and Venturi and Ferri (2001, p. 228, Fig. g). The species differs from C. dumortieri in having a subcircular section. The C. dumortieri specimen shown by Rulleau (1995, Pl. 4, Figs 3-4, re-illustrated by Rulleau and Mouterde 1997, Pl. 2, Fig. 1) possesses markedly wide whorls; its morphology seems to be closer to that of $C$. pannonicum.

Distribution: Pseudoradiosa Zone: Bulgaria. Aalensis Zone: France(?). Meneghinii - Aalensis Zones(?): Italy. Upper Toarcian: Southern Spain, Bakony Mts (Hungary). Gerecse Mts: Aalensis Zone: Nagy-Pisznice and Tölgyhát (A) sections. 


\section{Catulloceras raricostatum (Géczy, 1967)}

(Plate 5, Fig. 1)

v 1967 Dumortieria stefaninii? raricostata n. subsp. - Géczy, p. 142, Text-fig. 141; Pl. 31, Fig. 8; Pl. 64, Fig. 55

1968 Dumortieria raricostata Géczy - Levi Setti, p. 332, Text-figs 2/1, 3/4; Pl. 32, Fig. 3

1996 Dumortieria raricostata Géczy - Jakobs and Smith, p. 127, Pl. 3, Figs 20-21

2001 "Catulloceras" raricostatum Géczy - Venturi and Ferri, p. 228, Fig. h

Material: One moderately preserved internal mold.

$\begin{array}{lllllllll}\text { Measurements: } & \mathrm{D} & \mathrm{H} & \mathrm{h} & \mathrm{W} & \mathrm{w} & \mathrm{U} & \mathrm{u} & \mathrm{RLW} \\ 53.2011 & 76 & 20 & 26.3 \% & 18 & 90 \% & 40 & 52.6 \% & 43\end{array}$

Description: Evolute form, wide, gradually deepening umbilicus, slightly convex flank. Low venter, narrow, low keel, bordered by two shallow grooves. Wide-oval whorl-section with maximum width under the mid-height. The preserved body chamber is a quarter-whorl in length. Sharp, simple, rectiradiate ribs, projected at the shoulder, bend forward and fade away on the venter. Wider intercosta than the rib-width. Two wide, deep constrictions on the last whorl of the phragmocone. Suture-line: wide E, and narrower $L$ lobes with equal length, wide ES, asymmetrical LS, short, oblique U lobes.

Remarks: Based on the morphology the species is recognized as Catulloceras in this paper (see Rulleau and Mouterde 1997, p. 81). The Gerecse specimen is close to the holotype (Géczy 1967, Pl. 31, Fig. 8) in morphology, but differs slightly by less curved ribs, similar to what is illustrated by Levi Setti (1968, Pl. 32, Fig. 3). The species resembles $C$. dumortieri in its style of coiling, but differs by its wider interspaces. It is also similar to C.(?) strictum in widely spaced ribs, but differs in having a narrower suboval section (see Géczy 1967, p. 138).

Distribution: Levesquei Zone: Southern Spain. Upper Toarcian: Italy, North America, Bakonycsernye (Hungary). Gerecse Mts: Aalensis Zone: Kis-Gerecse section.

Catulloceras sp.

(Plate 5, Fig. 3)

$\begin{array}{lllllllll}\text { Measurements: } & \mathrm{D} & \mathrm{H} & \mathrm{h} & \mathrm{W} & \mathrm{w} & \mathrm{U} & \mathrm{u} & \text { RLW } \\ 54.2011 & 57 & 15 & 26.3 \% & 10 & 66.6 \% & 31 & 54.3 \% & 45\end{array}$

Description: A poorly preserved, wholly septate internal mold. Evolute coiling, shallow umbilicus. Rounded margin and shoulder, slightly convex flank. Narrow, low venter, weakly developed keel bounded by narrow sulci. Subrectangular whorl-section on the inner whorls, narrow suboval section with maximum width at the lower third on the last whorl. Simple, somewhat prorsiradiate, curved ribs, projected on the venter, fade away close to the carina producing ventral grooves. The suture-line cannot be traced in all details, but is typical of Catulloceras. 
Remarks: The morphology (evolute coiling, altering development) resembles that of Dumortieria meneghinii. The flattened ventral part with narrow sulci, however, is typical of Catulloceras. C. perroudi is a similar form in compressed subrectangular section, but differs by gradual development and straight, sharper ribs.

Distribution: Meneghinii Zone: Kis-Gerecse section.

\section{Genus Cotteswoldia Buckman 1902}

Type species: Cotteswoldia paucicostata Buckman 1904 (Pl. S. 23, Figs 1-3).

Diagnosis: Moderately evolute coiling, shallow umbilicus, rounded margin. Slightly convex flanks, high and narrow venter, ogival section. Weakly developed, irregular, simple, sinuous ribbing. Suture-line: small and wide E, slightly longer and wide L, weakly developed and straight U lobes, and wide ES and LS.

Remarks: The taxonomical validity of four closely related genera introduced by Buckman (Pleydellia 1899, Cotteswoldia 1902, Canavarina 1904, Walkericeras 1913) has been disputed in the literature. Arkell (1957), Géczy (1967), Donovan et al. (1981), and Jakobs and Smith (1996) regarded the latter three taxa as synonyms of Pleydellia; while others, such as Rulleau $(1995,2007)$, Rulleau et al. (2001), SeyedEmami et al. (2008), and Metodiev (2008) classified Cotteswoldia and Walkericeras as subgenera of Pleydellia. For morphological criteria, Cotteswoldia and Pleydellia were treated at generic level, for instance by Fauré and Cubaynes (1983), Goy and Ureta (1988), Henriques (1992), Ohmert (1993), Schulbert (2001), Fauré (2002), Henriques and Ureta (2002), Pallini et al. (2005), and Arp (2010). As Cotteswoldia differs from Pleydellia in morphology (evolute coiling, simple, irregular ribbing) and stratigraphic distribution, this classification is adopted here. The genus appears around the boundary between the Meneghinii/Pseudoradiosa and Aalensis Zones and seems to precede the first occurrence of Pleydellia (Ureta et al. 1999; Rulleau et al. 2001; El Hariri et al. 2006). Cotteswoldia disappeared in the Lugdunensis/Buckmani Subzone; it was replaced by Walkericeras in NW European localities. The taxonomic revision of some species which were designated primarily as Cotteswoldia seems to be reasonable (Ohmert 1993; Schulbert 2001; Arp 2010). The style of coiling and the furcate ribs permit, for example, the reclassification of $C$. subcandida Buckman and C. misera Buckman as Pleydellia.

In the Gerecse sections four species are represented by 13 specimens: $C$. paucicostata Buckman, C. tenuiplicata (Géczy), C. cf. particostata Buckman and C. cf. bifax Buckman. C. tenuiplicata and C. crinita Buckman are known from the Bakony Mts (Géczy 1967, 1968). Beside Pleydellia, Cotteswoldia was used as index taxon of the Aalensis Zone by Kovács and Géczy (2008).

Distribution: Meneghinii/Pseudoradiosa - Aalensis Zones: Europe, North Africa, Crimea, Caucasus, Iran. 


\section{Cotteswoldia paucicostata Buckman, 1904}

(Plate 6, Fig. 3)

1904 Cotteswoldia paucicostata - Buckman, p. S. 133, Pl. S23, Figs 1-3

1966 Cotteswoldia paucicostata Buckman - Nutsubidze, p. 114, Pl. 23, Fig. 6

2001 Pleydellia (Cotteswoldia) paucicostata Buckman - Rulleau et al., Pl. 17, Figs 1-2

2002 Cotteswoldia gr. paucicostata Buckman - Fauré, p. 732, Pl. 22, Figs 15-16; Pl. 25, Fig. 5

2005 Pleydellia (Cotteswoldia) paucicostata Buckman - Seyed-Emami et al., p. 363, Fig. 6/H, I

2005 Cotteswoldia paucicostata Buckman - Pallini et al., p. 10, Pl. 5, Fig. 8

2008 Pleydellia (Cotteswoldia) paucicostata Buckman - Metodiev, Fig. 6/x

Material: One moderately preserved internal mold.

$\begin{array}{llllllll}\text { Measurements: } & \mathrm{D} & \mathrm{H} & \mathrm{h} & \mathrm{W} & \mathrm{w} & \mathrm{U} & \mathrm{u} \\ 55.2011 & 100 & 35 & 35 \% & 18 & 51.4 \% & 36 & 36 \%\end{array}$

Description: Moderately evolute form, shallow umbilicus, high, steep umbilical wall, rounded margin. Slightly convex flank; narrow, high, carinate venter, fastigate on the body chamber. Ogival section with maximum width at the lower third. The body chamber is three-quarters whorl in length. Oblique, slightly projected peristome. Sharp, simple, widely spaced ribs on the inner, and dense, sigmoid, weakly developed ribs on the last whorl. Suture-line: short, wide E, slightly longer, wide L, short, straight U lobes, wide ES and LS.

Remarks: The Gerecse specimen agrees with the type (Buckman, 1904, Pl. S23, Figs $1-3)$ in morphology, but slightly differs in weakly developed ribs on the body chamber. It is very close to the specimen shown by Rulleau et al. (2001, Pl. 17, Fig. 1). C. particostata and C. bifax are similar forms in morphology, but differ by their denser ribs.

Distribution: Aalensis Zone: Great Britain, France, Northern Spain, Portugal, Italy, Bulgaria, North Africa, Crimea, Caucasus, Iran. Gerecse Mts: Aalensis Zone: Nagy-Pisznice.

\section{Cotteswoldia tenuiplicata (Géczy, 1967)}

(Plate 7, Fig. 2)

v 1904 Harpoceras (Grammoceras) laevigatum, nov. sp. Hantken - Prinz, p. 107, Pl. 23, Fig. 1; Pl. 34-35, Fig. 7

v 1967 Pleydellia laevigata (Hantken in Prinz) - Géczy, p. 155, Text-fig. 158, Pl. 35, Fig. 1; Pl. 64, Fig. 69 v 1967 Pleydellia laevigata tenuiplicata n. subsp. - Géczy, p. 156, Text-fig. 159, Pl. 35, Fig. 2; Pl. 64, Fig. 72

Material: Eight internal molds in varying states of preservation (56.2011-63.2011).

$\begin{array}{clllllll}\text { Measurements: } & \mathrm{D} & \mathrm{H} & \mathrm{h} & \mathrm{W} & \mathrm{w} & \mathrm{U} & \mathrm{u} \\ 56.2011 & 114 & 32 & 28 \% & 15 & 46.8 \% & 56 & 49 \% \\ 57.2011 & 106 & 31 & 29.2 \% & 14 & 45 \% & 51 & 48 \% \\ 58.2011 & 98 & 29 & 29.5 \% & 13 & 44.8 \% & 48 & 49 \% \\ 59.2011 & 91 & 26 & 28.5 \% & 12 & 46 \% & 43 & 47.2 \%\end{array}$


Description: Evolute, compressed form, shallow umbilicus, low umbilical wall, rounded margin. Slightly convex flank; narrow, high, carinate venter. Ogival whorl-section with maximum width at the lower third. The body chamber is about three-quarters whorl in length. Well-developed, simple, straight, rectiradiate ribs, rise from the umbilicus, curve forward on the ventrolateral part, fade away at the keel. The interspaces are the same as the rib-width. About 40 ribs are characteristic on the last whorl of the phragmocone. Weakly-developed sculpture on the body chamber. Suture-line: moderately wide E, longer and wide, somewhat asymmetrical L, short, slightly oblique U lobes, wide ES, narrower LS.

Remarks: Since the two P. laevigata specimens described by Prinz (1904) differ in ornamentation, a subspecies was designated by Géczy (1967) assigning the specimen illustrated by Prinz (l.c.) on Plate 23 (Fig. 1) as type. All Gerecse specimens with relatively dense ribs are closer to P. laevigata tenuiplicata Géczy. Based on this material and the lack of a detailed record of $P$. laevigata from other localities, the subspecies is recognized as a specific form, and emended at species level here. The morphology and the suture construction agree with those of Cotteswoldia; therefore the new taxon is placed in this genus. The Gerecse specimens are close to the type; however, the irregular bifurcation of ribs (Géczy 1967, p. 156) cannot be traced. The species differs from other Cotteswoldia in morphology by marked evolute coiling. Outside of Hungary C. tenuiplicata was recorded from Morocco (Benshili 1989, p. 165) without any description.

Distribution: Aalensis Zone: Morocco. Upper Toarcian: Bakony Mts (Hungary). Gerecse Mts: Aalensis Zone: Nagy-Pisznice, Kis-Gerecse.

\section{Cotteswoldia cf. particostata Buckman, 1904}

(Plate 6, Fig. 2)

1904 Cotteswoldia particostata - Buckman, p. S.133, Pl. S23, Figs 5-7

1940 Cotteswoldia particostata Buckman - Gérard and Bichelonne, p. 36, Pl. 9, Fig. 1

1995 Pleydellia (Cotteswoldia) particostata Buckman - Rulleau, p. 6, Pl. 11, Fig. 7

1995 Pleydellia (Cotteswoldia) aff. particostata Buckman - Rulleau, Pl. 12, Fig. 1

2007 Pleydellia (Cotteswoldia) particostata Buckman - Rulleau, p. 93, Pl. 53, Fig. 9

Material: One deformed internal mold (64.2011: D. appr. 86).

Description: Moderately evolute form, shallow umbilicus, low umbilical wall, rounded margin. Slightly convex flank; narrow, high, carinate venter. Ogival section with maximum width at the lower third. The preserved body chamber is a half whorl in length. Sharp, simple ribs on the inner, and denser, sigmoid, weakly developed ribs on the last whorl. The suture line cannot be traced in all details, but is typical of Cotteswoldia.

Remarks: The Gerecse specimen agrees with the type (Buckman 1904, Pl. S23, Figs $5-7)$, but differs slightly in somewhat widely spaced ribs on the inner whorls, and weakly developed ribs on the body chamber. It is close to $P$. $(C$.) aff. particostata 
shown by Rulleau (1995, Pl. 12, Figs 1-2). C. paucicostata is close in morphology, but characterized by a rounded umbilical wall and stronger ribs. C. bifax is similar in style of coiling, but differs in having denser ribs.

Distribution: Aalensis Zone: Great Britain, France, Northern Spain, Morocco. Gerecse Mts: Aalensis Zone: Nagy-Pisznice section.

\section{Cotteswoldia cf. bifax Buckman, 1904}

(Plate 4, Fig. 2)

1904 Cotteswoldia bifax-Buckman, p. S136, Fig. 110A

1940 Cotteswoldia bifax Buckman - Gérard and Bichelonne, p. 36, Pl. 11, Fig. 6

1988 Cotteswoldia bifax Buckman - Goy and Ureta, p. 25, Pl. 1, Figs 6-7

1995 Pleydellia (Cotteswoldia) bifax Buckman - Rulleau, Pl. 10, Fig. 7; Pl. 11, Figs 8-9

2005 Pleydellia (Cotteswoldia) bifax Buckman - Seyed-Emami et al., p. 362, Fig. 6/K, L

v 2007 Pleydellia (Cotteswoldia) bifax Buckman - Galácz et al., p. 348, Fig. 4/10

2008 Pleydellia (Cotteswoldia) bifax Buckman - Seyed-Emami et al., p. 252, Fig. 5/P

Material: One fragmentary internal mold.

$\begin{array}{clllllll}\text { Measurements: } & \mathrm{D} & \mathrm{H} & \mathrm{h} & \mathrm{W} & \mathrm{w} & \mathrm{U} & \mathrm{u} \\ 65.2011 & 88 & 26 & 29.5 \% & 12 & 46 \% & 39 & 44.3 \%\end{array}$

Description: Evolute, compressed form, shallow umbilicus, rounded margin slightly convex flank, narrow, high, rounded venter. Carina cannot be traced. High suboval whorl-section with maximum width above the margin. The preserved body chamber is a half whorl in length. Strong, rectiradiate ribs on the inner, less developed and more widely-spaced ribs on the external whorls. The suture-line is typical of Cotteswoldia.

Remarks: The specimen is similar to the type (Buckman 1904, p. S136, Fig. 110A) and to the specimens shown by Rulleau (1995, Pl. 11, Figs 8-9) and Seyed-Emami et al. (2005, Fig. 6/L) in morphology, but differs in having weaker ribs on both the penultimate and the last whorls. The weakly-developed sculpture resembles that of Pleydellia leura (Buckman), but it is a more involute form with a higher umbilical wall, and bears widely-spaced simple ribs on the inner whorls.

Distribution: Aalensis Zone: England, France, northern Spain, Italy, Bulgaria, Iran Gerecse Mts: Aalensis Zone: Tölgyhát (A) section.

\section{Genus Pleydellia Buckman, 1899}

Type species: Ammonites aalensis Zieten, 1832; designated by Buckman (1904). The mold of the type specimen was re-illustrated by Rulleau (1995, Pl. 13, Figs 8-9) and Elmi et al. (1997, Pl. 11, Figs 15-16).

Diagnosis: Moderately evolute to involute, compressed coiling, shallow umbilicus, rounded margin. Slightly convex flanks, high and narrow venter, ogival to subtriangular section. Strong to weak sinuous ribbing. Bifurcation is 
characteristic near the margin. Weakly-developed suture line with wide E, slightly longer and wide L, small, straight U lobes, wide ES and LS.

Remarks: There is no consensus on the taxonomic interpretation of the genus and the arrangement of species, primarily assigned as Cotteswoldia, Pleydellia, Walkericeras or Canavarina. Some arguments suggest reduction in the literature: the elemental constructions of the lobes are almost identical; the morphologies of different species are similar: the differences in the style of coiling might be interpreted within a single genus; the sections resemble each other and the sculptures show only moderate differences. The stratigraphic ranges of the genera, however, differ. Only the validity of Pleydellia was accepted by Arkell (1957), Géczy (1967), Donovan et al. (1981), and Jakobs and Smith (1996); the validity of Walkericeras was rejected, and the respective species were reclassified as Cotteswoldia, for instance by Ohmert (1993), Schulbert (2001) and Arp (2010); Cotteswoldia, Walkericeras and Canavarina (?) were considered as subgenera of Pleydellia, among others by Rulleau et al. (2001), while Cotteswoldia and Pleydellia were recognized at generic level with the subgenus $P$. (Walkericeras) by Fauré (2002). Pleydellia is thought to derive from Dumortieria; it flourished during the Aalensis Zone, and disappeared in the lowermost Opalinum Subzone.

In the Gerecse material a single species is represented by seven poorlypreserved specimens of Pleydellia (Pleydellia) subcompta (Branco). Prior to the above-mentioned great collection work, two "Harpoceras aalense Zieten (var.)" specimens were described by Staff (1906, pp. 208-209) from Nagy-Pisznice Hill. Figures were not provided, but the author referred to the P. aalensis specimen illustrated by Buckman (1904, Pl. 32, Fig. 4) as the closest example, which was later regarded as P. (Walkericeras) lugdunensis Elmi et Rulleau by Elmi et al. (1997). Staff's specimens cannot be traced now, and the subsequent collection works have not yielded this important index taxon, so its occurrence in the Gerecse Mts remains uncertain. The diversity of the genus was higher in the Csernye section: six species were recorded by the present classification: P. subcompta, P. aalensis, $P$. mactra (Dumortier), P.? hammatoceratoides Géczy, P.? (Walkericeras) dudelangensis Maubeuge and P. (Walkericeras) burtonensis (Buckman) (Géczy 1967). Three species are known from Úrkút: $P$. cf. aalensis, $P$. (Walkericeras) cf. dudelangensis, and $P$. (Walkericeras) cf. burtonensis (Géczy 1968), and one from Szentgál. The P. cf. subcompta recorded from the latter section (Géczy 1975) is recognized here as $P$. cf. aalensis.

Distribution: Aalensis Zone: worldwide range. Aalensis Zone - Opalinum Subzone: Germany, Portugal, northern Spain.

Pleydellia (Pleydellia) subcompta (Branco, 1879)

(Plate 6, Fig. 1)

1879 Harpoceras subcomptum n. sp. - Branco, p. 90, Pl. 5, Figs 3-4

1966 Grammoceras subcomptum Branco - Nutsubidze, p. 99, Pl. 22, Figs 1-2 (cum syn.) 
1967 Pleydellia cf. subcompta (Branco) - Géczy, p. 150, Text-fig. 151; Pl. 34, Fig. 1; Pl. 64, Fig. 64 1985 Pleydellia subcompta (Branco) - Seyed-Emami and Nabavi, p. 264, Figs 30-31

1994 Pleydellia (Pleydellia) subcompta (Branco) - Goy et al., Pl. 2, Fig. 8

1995 Pleydellia subcompta (Branco) - Rulleau, Pl. 13, Figs 4-6

1997 Pleydellia subcompta (Branco) - Metodiev, p. 22, Pl. 4, Fig. 6

2000 Pleydellia subcompta (Branco) - Henriques, Pl. 1, Fig. 2

2001 Cotteswoldia subcompta (Branco) - Schulbert, p. 85, Text-fig. 4.4/e; Pl. 11, Figs 1-2, 5, 9-10; Pl. 30,

Fig. 1 (cum syn.)

2002 Pleydellia (P. ?) subcompta (Branco) - Fauré, p. 730, Pl. 22, Fig. 11

2004 Pleydellia subcompta (Branco) - Myczynski, p. 66, Fig. 25/4

2005 Pleydellia (Pleydellia) subcompta (Branco) - Pallini et al., p. 10, Pl. 4, Fig. 7

2008 Pleydellia (Pleydellia) subcompta (Branco) - Seyed-Emami et al., p. 251, Fig. 5/H

2010 Pleydellia subcompta (Branco) - Arp, p. 41, Pl. 2, Figs 17-18

Material: Four internal moulds in varying states of preservation (66.2011-69.2011).

$\begin{array}{clllllll}\text { Measurements: } & \mathrm{D} & \mathrm{H} & \mathrm{h} & \mathrm{W} & \mathrm{w} & \mathrm{U} & \mathrm{u} \\ 67.2011 & 80 & 26 & 32.5 \% & 10 & 38.4 \% & 34 & 42.5 \%\end{array}$

Description: Moderately evolute, compressed form, shallow umbilicus, low umbilical wall, rounded margin. Slightly convex flank; narrow, high venter, fine, sharp keel. Flattened-oval whorl-section with maximum width at one-fourth of the whorl height. Whole body chamber not preserved. Fine, dense, sinuous ribs bundling in four or five at the margin on the inner whorls. Less developed, widely spaced ribs without bundles on the last whorl of the phragmocone. Suture line: short, wide E, longer, wide L, small, straight U lobes, wide ES and LS.

Remarks: The specimens are close to the type (Branco, 1879, Pl. 5, Fig. 3) in morphology, and to the specimens illustrated, for instance, by Benecke (1905, Pl. 46, Fig. 2), Seyed-Emami and Nabavi (1985, Fig. 31), Goy et al. (1994, Pl. 2, Fig. 8), and Rulleau (1995, Pl. 13, Figs 4-6). Apart from the fasciculate ribbing of $P$. subcompta, $P$. mactra (Dumortier) differs in having finer and regular ribs, while $P$. aalensis bears coarser sculpture. The species was classified as Cotteswoldia by Ohmert (1993), Ohmert and Rolf (1994), and Schulbert (2001) due to its evolute coiling and suture-construction, but this arrangement has not been accepted in the literature.

Distribution: Aalensis Zone: Europe, North Africa, Caucasus, Iran. Upper Toarcian: Bakonycsernye (Hungary). Gerecse Mts: Aalensis Zone: Nagy-Pisznice and Tölgyhát (A) sections.

\section{Subfamily Tmetoceratinae Spath, 1936}

Genus Tmetoceras Buckman, 1892

Type species: Ammonites scissus Benecke, 1865; designated by Buckman (1892).

Diagnosis: Moderately evolute to evolute, planulate coiling, convex flanks, low venter with deep median groove, subrectangular to subcircular whorl-section. 
Sharp, strong, straight, simple ribs; constrictions can be present. Simple sutureline with short E, long L, small, straight U lobes, wide, slightly divided ES and LS. Remarks: The genus was recently discussed by Callomon and Chandler (1994), Rulleau and Mouterde (1997), Fernández-López et al. (1999a, 1999b), Rulleau et al. (2001), Venturi and Ferri (2001), Sandoval (2002), Myczynski (2004), Pallini et al. (2005) and Venturi et al. (2010). Tmetoceras appeared in the Late Toarcian, flourished during the Aalenian, and disappeared in the Concavum Zone. According to morphologic criteria it is thought to derive from Catulloceras but the dissimilar suture constructions raise difficulties in phylogenetic interpretations (Schindewolf 1964). Nor is there any consensus in the literature on the successors of Tmetoceras. The genus is characterized by sexual dimorphism; microconchs were recorded from Alaska, South America, England, Spain, Portugal and Poland.

In the Gerecse assemblage a single species is represented by 3 specimens of $T$. scissum (Benecke). The species was abundant in Bakonycsernye with 39 specimens, and also known from Úrkút (Géczy 1967, 1968). Although in remarkably low numbers, T. scissum does occur in three Gerecse sections.

Distribution: Upper Aalensis Zone - Aalenian: Mediterranean and NW European Provinces. Aalenian: worldwide range.

Tmetoceras scissum (Benecke, 1865)

(Plate 5, Figs 2, 4)

1865 Ammonites scissus - Benecke, p. 170, Pl. 6, Fig. 4

v 1967 Tmetoceras scissum (Benecke) - Géczy, p. 160, Text-fig. 162; Pl. 35, Figs 3-7; Pl. 64, Figs 73-74

(cum syn.)

1994 Tmetoceras scissum (Benecke) - Callomon and Chandler, p. 27, Pl. 5, Figs 2-3; Pl. 6, Fig. 3; Pl. 8,

Figs 2-4

1999a Tmetoceras scissum (Benecke) - Fernández-López et al., p. 94, Text-figs 2-4; Fig. 8/A-N; Fig. 9/FQ (cum syn.)

1999b Tmetoceras scissum (Benecke) - Fernández-López et al., Text-figs 4, 8, 10, 12, 14, 16; Fig. 3/A-D, F-G

2002 Tmetoceras scissum (Benecke) - Sandoval, p. 163, Figs 101-102

2004 Tmetoceras scissum (Benecke) - Myczynski, p. 71, Fig. 26/4-6

2005 Tmetoceras scissum (Benecke) - Pallini et al., p. 11, Pl. 5, Figs 1-2

2007 Tmetoceras scissum (Benecke) - Rulleau, p. 93, Pl. 52, Fig. 7

Material: Three poorly preserved internal molds (70.2011-72.2011).

$\begin{array}{cllllllll}\text { Measurements: } & \mathrm{D} & \mathrm{H} & \mathrm{h} & \mathrm{W} & \mathrm{w} & \mathrm{U} & \mathrm{u} & \mathrm{RLW} \\ 70.2011 & 72 & 20 & 27.7 \% & 18 & 90 \% & 37 & 51.4 \% & 52 \\ 71.2011 & 51 & 13 & 25.5 \% & 10 & 77 \% & 27 & 53 \% & 44(?)\end{array}$

Description: Evolute form, relatively deep umbilicus, rounded margin. Convex flank, low venter, deep median ventral groove. Rounded subrectangular whorlsection. Whole body chamber not preserved. Sharp, straight, rectiradiate, simple ribs interrupted by ventral groove. Three constrictions on the last whorl. No visible suture line. 
Remarks: The Gerecse specimens are close to the type (Benecke, 1865, Pl. 6, Fig. 4), as well as to the specimens illustrated by Géczy (1967, Pl. 35, Figs 4-7), and more recently for instance by Fernández-López et al. (1999a, Fig. 8/A-C, E-F, J; Fig. 9/K $\mathrm{M}-\mathrm{N}$ ) and Sandoval (2002, Fig. 102/a-d, $\mathrm{k}-\mathrm{l}$ ). The species is characterized by slight variability in density and direction of the ribs. T. difalense (Gemmellaro) differs in more involute coiling and sigmoid ribs, while T. regleyi (Thiolliere in Dumortier) is characterized by wider whorls with a subcircular section.

Distribution: see the genus. Bakony Mts (Hungary): Aalenian. Gerecse Mts: Opalinum Zone: Kis-Gerecse, Comptum Subzone: Tölgyhát (A), Murchisonae Subzone: Nagy-Pisznice sections.

\section{Conclusions}

The taxonomic study of the Toarcian-Aalenian Ammonitina assemblage of the Gerecse Mts identified 15 species that belong to the Tmetoceratidae. The uppermost Toarcian fauna is characterized by the abundance of the subfamily Dumortieriinae with the dominance of Dumortieria. The diversity of Dumortieria, Catulloceras and Tmetoceras is similar to that known from the Bakony Mts, and characterized mainly by Mediterranean taxa, whereas the diversity of the cosmopolitan Cotteswoldia is higher, and that of Pleydellia much lower. The taxonomic composition of the Tmetoceratidae fauna is very similar to that of other Mediterranean localities. Some genera allowed recognizing the Meneghinii and Aalensis chronozones without, however, further subzonal-level subdivisions. All taxa described from the Meneghinii Zone are typical of the standard Levesquei Subzone; beside the fine-ribbed group of Dumortieria the genera Hudlestonia and Pseudolioceras are absent from the fauna, so the Pseudoradiosa Subzone cannot be recognized. The co-occurrence of D. meneghinii and D. evolutissima with Pleydellia and Cotteswoldia in the lower Aalensis Zone is explained by the highly condensed nature of the Upper Toarcian strata of the Gerecse sections. The Pleydellia and Cotteswoldia species in the studied sections are characteristic of the standard Mactra Subzone, whereas taxa that are typical of the Aalensis/Lugdunensis Subzone in the NW European region (e.g. Pleydellia buckmani Maubeuge, P. fluens Buckman, P. leura Buckman, or the subgenus Walkericeras) are unknown from the Gerecse material. Tmetoceras is widely distributed in the Aalenian of different Mediterranean localities of Hungary, but is less abundant in the Gerecse than in the Bakony Mts.

\section{Acknowledgements}

I thank the following for professional help: Barnabás Géczy, András Galácz, Miklós Kázmér, József Pálfy and István Szente (Eötvös Loránd University, Budapest), Soledad Ureta (Madrid), Louis Rulleau (Lyon), Federico Venturi (Perugia) and Stefano Sassaroli (Rosora). Constructive reviews by José Sandoval (Granada) and Maria Helena Henriques (Coimbra) helped improve the manuscript. 
Plate 1

All illustrated specimens are coated with ammonium chloride, and shown in natural size (except $\mathrm{Pl}$. 3, Fig. 1). The beginning of the body chamber is marked by an arrow. Inventory numbers of the Natural History Museum of the Faculty of Science, Eötvös Loránd University, are given in parentheses.

Fig. 1a-b. Dumortieria meneghinii (Zittel in Haug), (10.2011), Kis-Gerecse, Meneghinii Zone. Ventral and lateral views

Fig. 2. Dumortieria meneghinii (Zittel in Haug), (08.2011), Bánya-hegy, Meneghinii Zone. Lateral view

Plate 2

Fig. 1. Dumortieria levesquei (d'Orbigny), (03.2011), Nagy-Pisznice, Meneghinii Zone. Lateral view

Fig. 2. Dumortieria cf. tabulata Buckman, (45.2011), Kis-Gerecse, Aalensis Zone. Lateral view

Fig. 3a-b. Dumortieria latumbilicata (Géczy), (43.2011), Nagy-Pisznice, Aalensis Zone. Lateral and ventral views

Fig. 4. Dumortieria meneghinii (Zittel in Haug), (11.2011), Kis-Gerecse, Meneghinii Zone. Lateral view

Plate 3

Fig. 1a-b. Dumortieria evolutissima Prinz, (31.2011), Nagy-Pisznice, Aalensis Zone. Ventral and lateral views, $\times 0.9$

Fig. 2a-b. Catulloceras pannonicum (Géczy), (51.2011), Nagy-Pisznice, Aalensis Zone. Lateral and ventral views

Plate 4

Fig. 1a-b. Dumortieria striatulocostata (Quenstedt), (44.2011), Kis-Gerecse, Meneghinii Zone. Lateral and ventral views

Fig. 2a-b. Cotteswoldia cf. bifax Buckman, (65.2011), Tölgyhát (A), Aalensis Zone. Lateral and ventral views

Fig. 3. Catulloceras dumortieri (Thiolliere in Dumortier), (46.2011), Nagy-Pisznice, Aalensis Zone. Lateral view

Plate 5

Fig. 1a-b. Catulloceras raricostatum (Géczy), (53.2011), Kis-Gerecse, Aalensis Zone. Ventral and lateral views

Fig. 2a-b. Tmetoceras scissum (Benecke), (71.2011), Tölgyhát (A), Comptum Subzone. Ventral and lateral views

Fig. 3a-b. Catulloceras sp., (54.2011), Kis-Gerecse, Meneghinii Zone. Ventral and lateral views

Fig. 4. Tmetoceras scissum (Benecke), (70.2011), Nagy-Pisznice, Murchisonae Subzone. Lateral view

Fig. 5. Dumortieria levesquei (d'Orbigny), (04.2011), Nagy-Pisznice, Aalensis Zone. Lateral view

Plate 6

Figs 1a-b. Pleydellia (Pleydellia) subcompta (Branco), (67.2011), Nagy-Pisznice, Aalensis Zone. Lateral and ventral views

Fig. 2. Cotteswoldia cf. particostata Buckman, (64.2011), Nagy-Pisznice, Aalensis Zone. Lateral view

Fig. 3a-b. Cotteswoldia paucicostata Buckman, (55.2011), Nagy-Pisznice, Aalensis Zone. Ventral and lateral views

Plate 7

Fig. 1a-b. Dumortieria evolutissima Prinz, Tölgyhát (A), (33.2011), Aalensis Zone. Lateral and ventral views

Fig. 2a-b. Cotteswoldia tenuiplicata (Géczy), (56.2011), Nagy-Pisznice, Aalensis Zone. Ventral and lateral views 
366 Z. Kovács

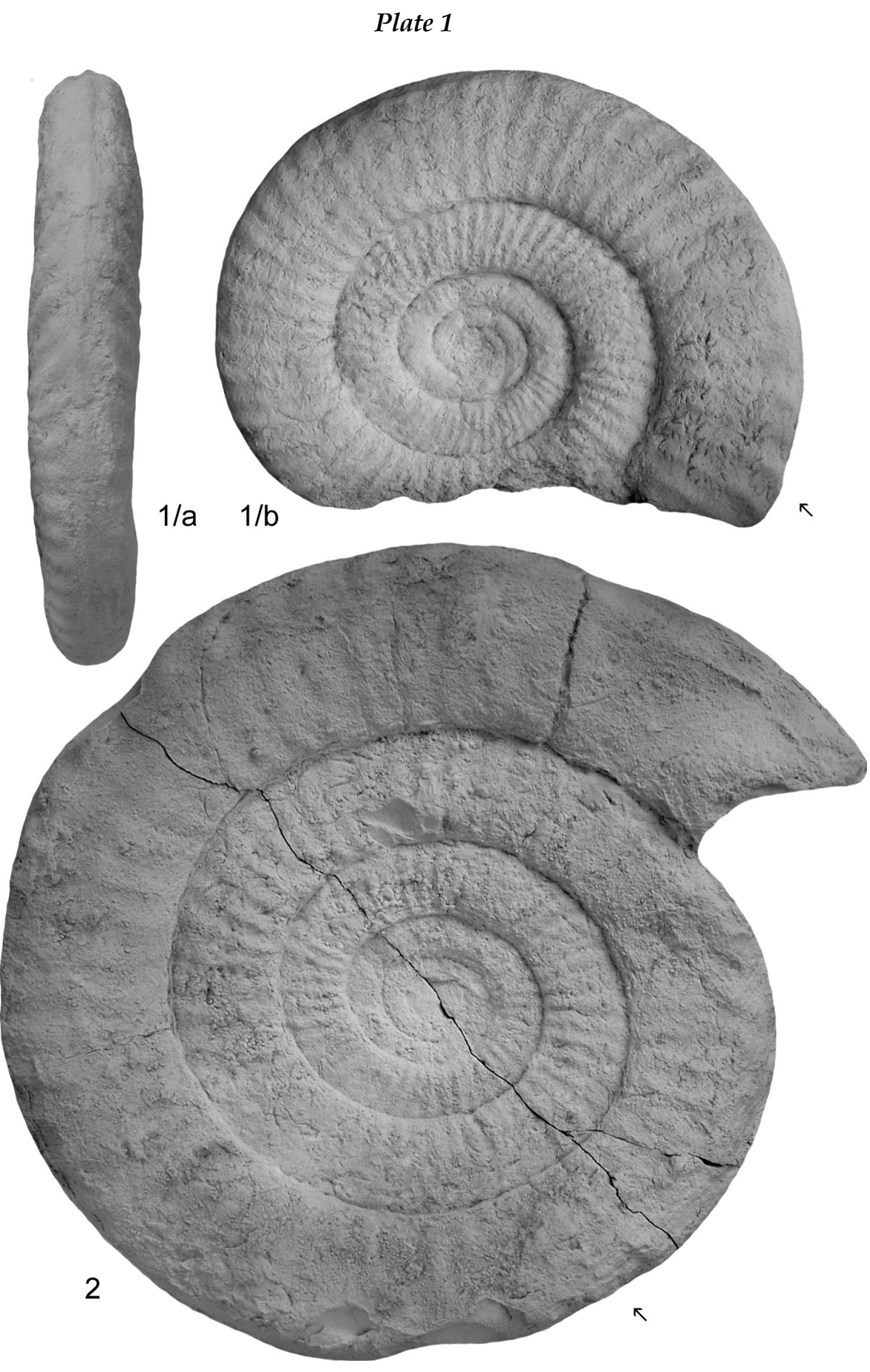

Central European Geology 53, 2010 
Tmetoceratidae (Ammonitina) fauna from the Gerecse Mts (Hungary) 367

Plate 2
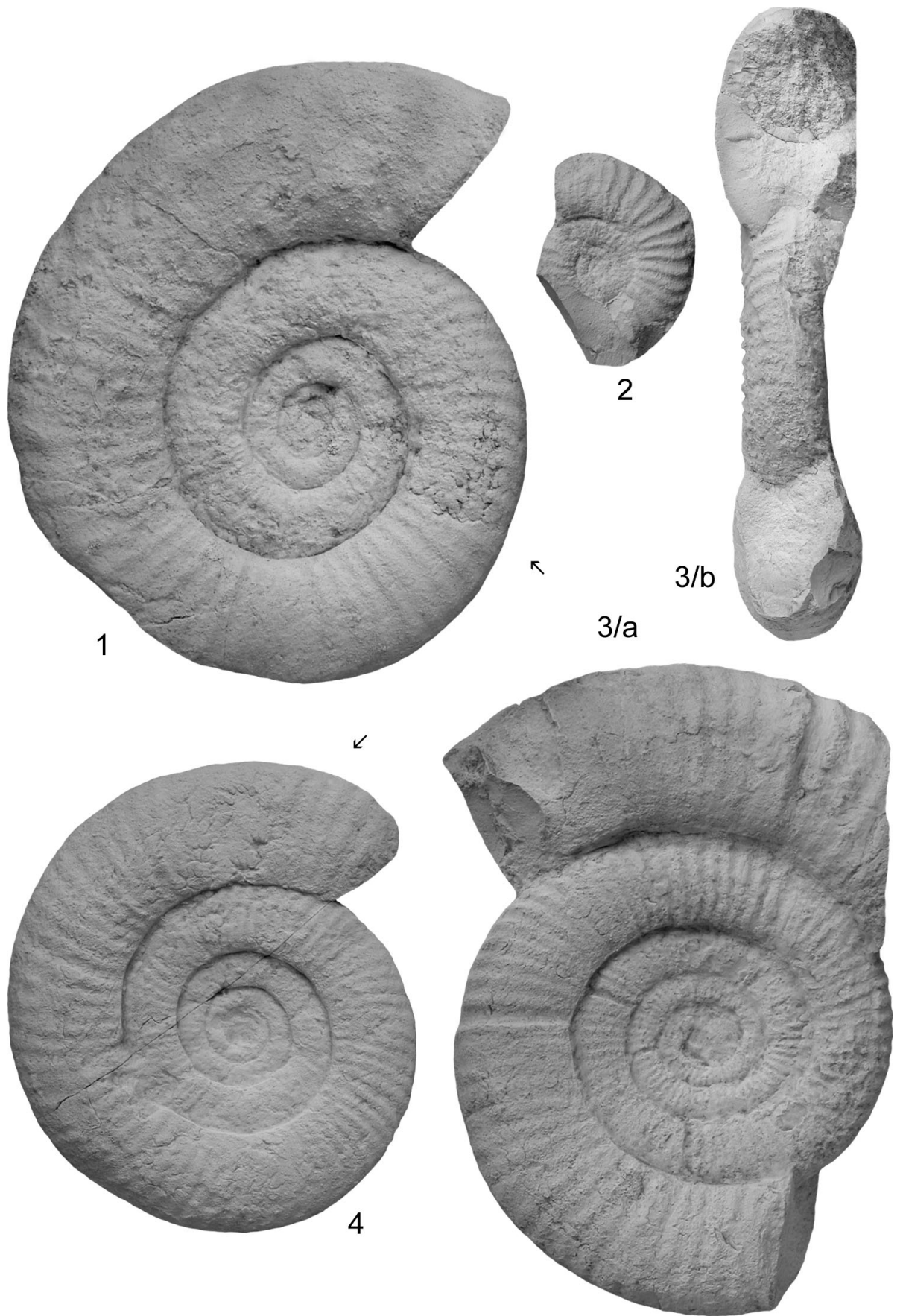

Central European Geology 53, 2010 
368 Z. Kovács

Plate 3

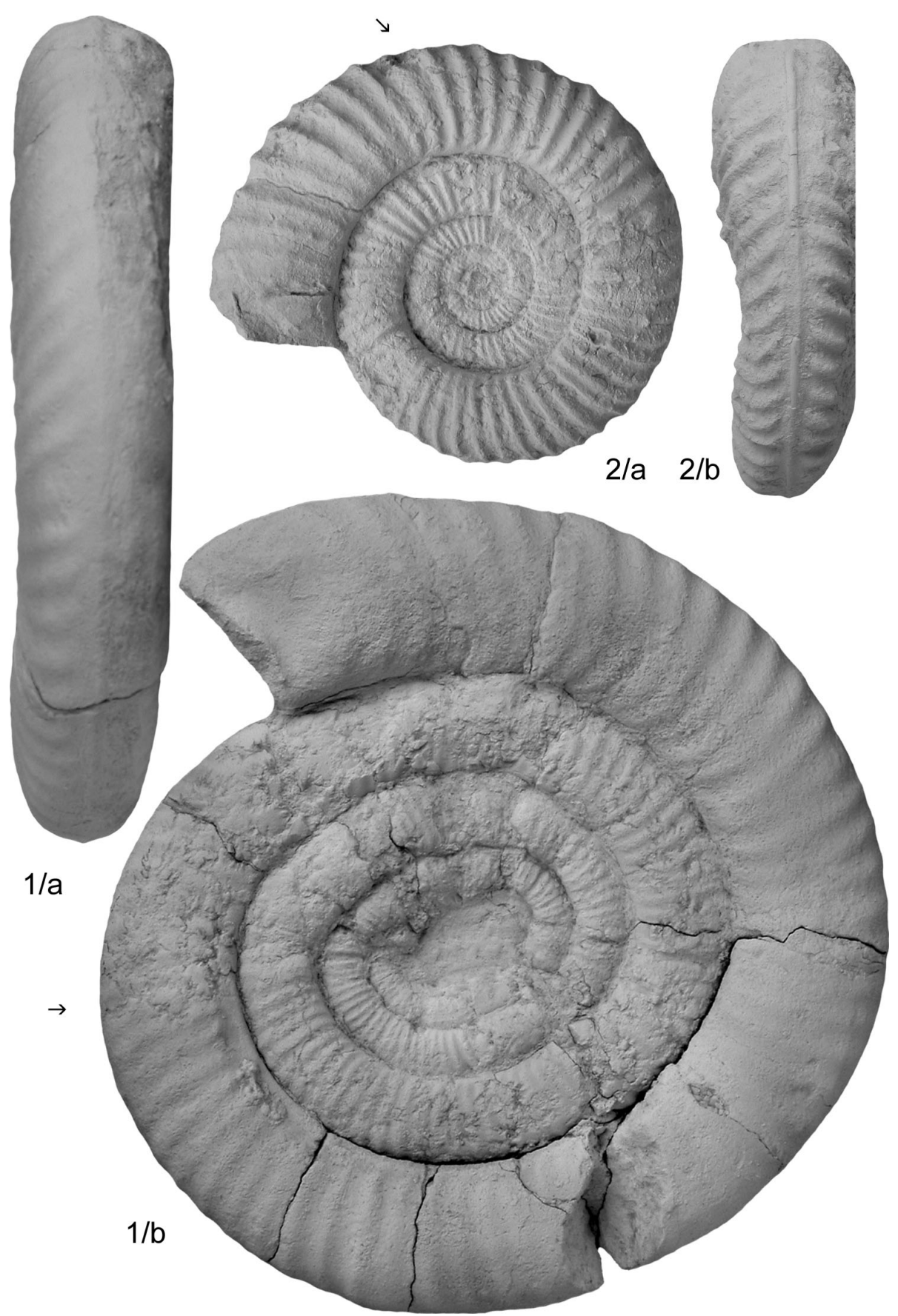

Central European Geology 53, 2010 
Tmetoceratidae (Ammonitina) fauna from the Gerecse Mts (Hungary) 369

\section{Plate 4}
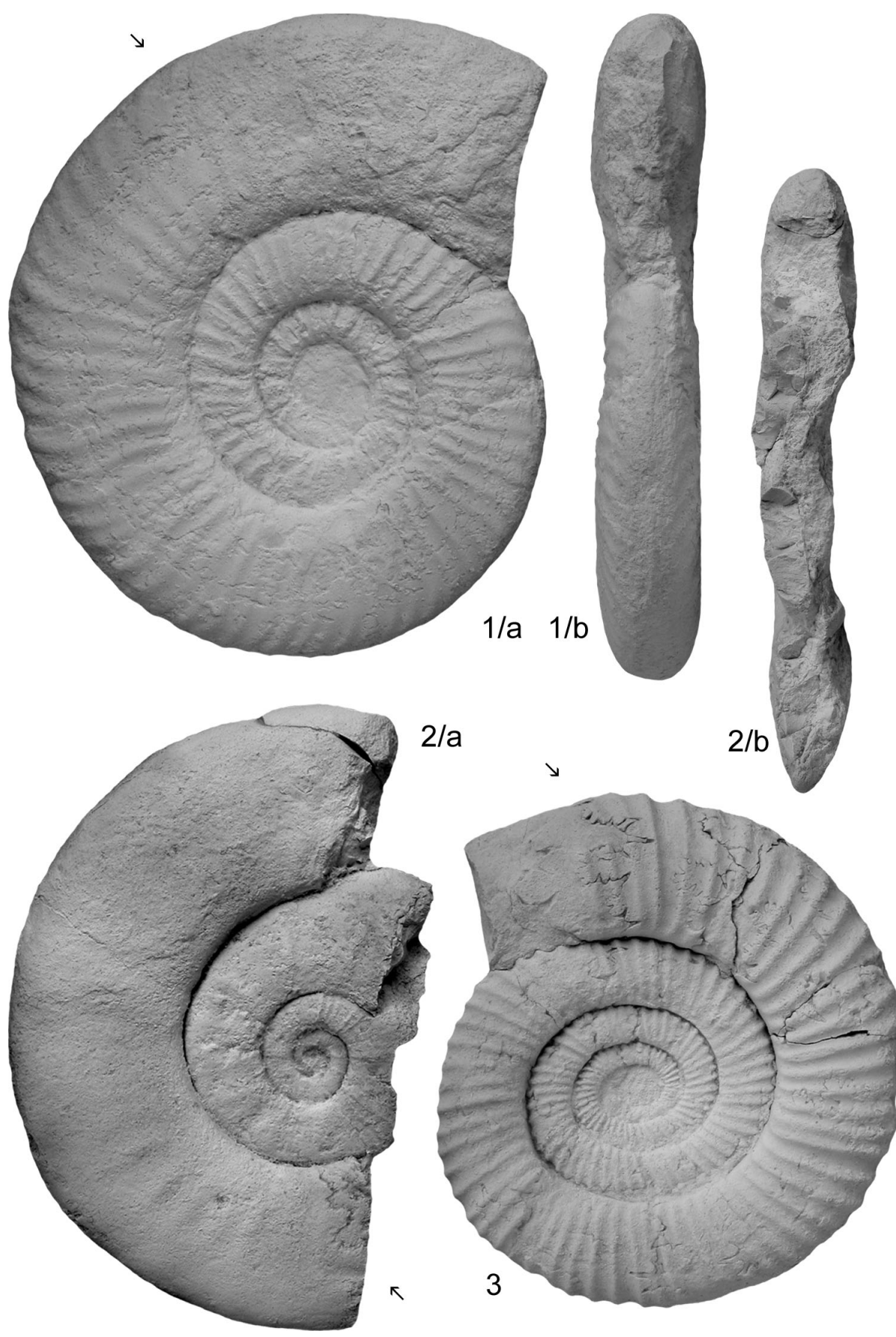

Central European Geology 53, 2010 
Plate 5

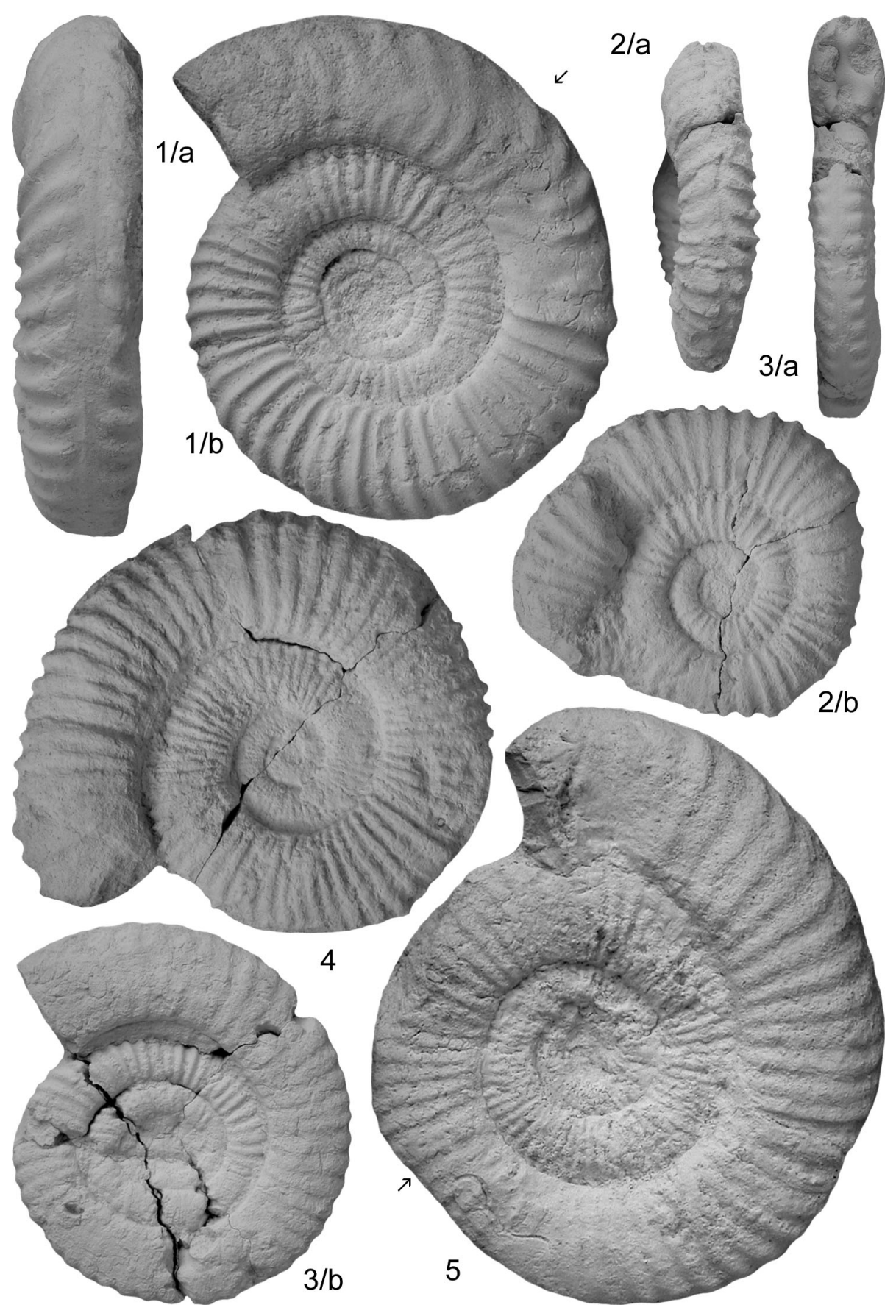

Central European Geology 53, 2010 
Tmetoceratidae (Ammonitina) fauna from the Gerecse Mts (Hungary) 371

Plate 6

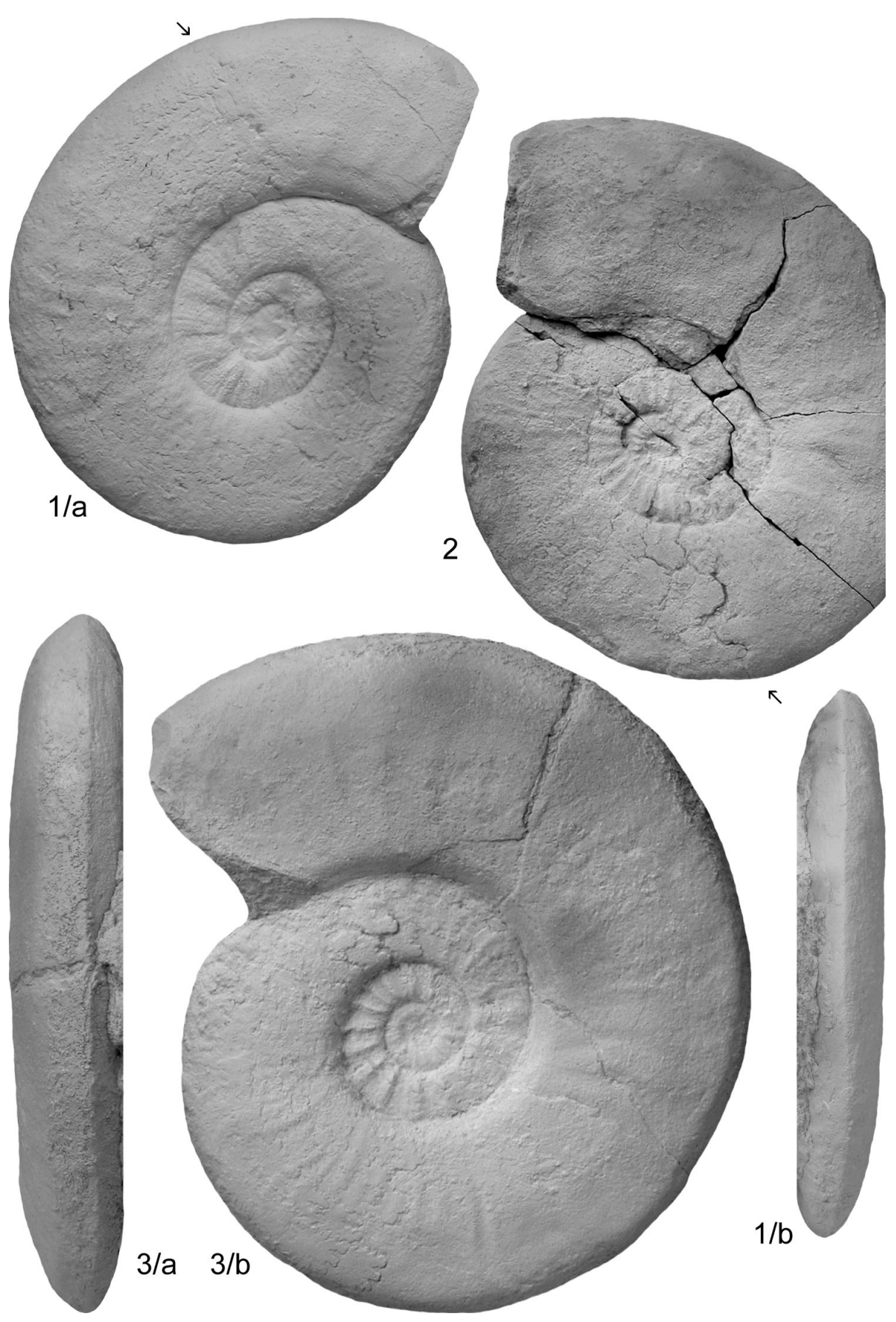

Central European Geology 53, 2010 


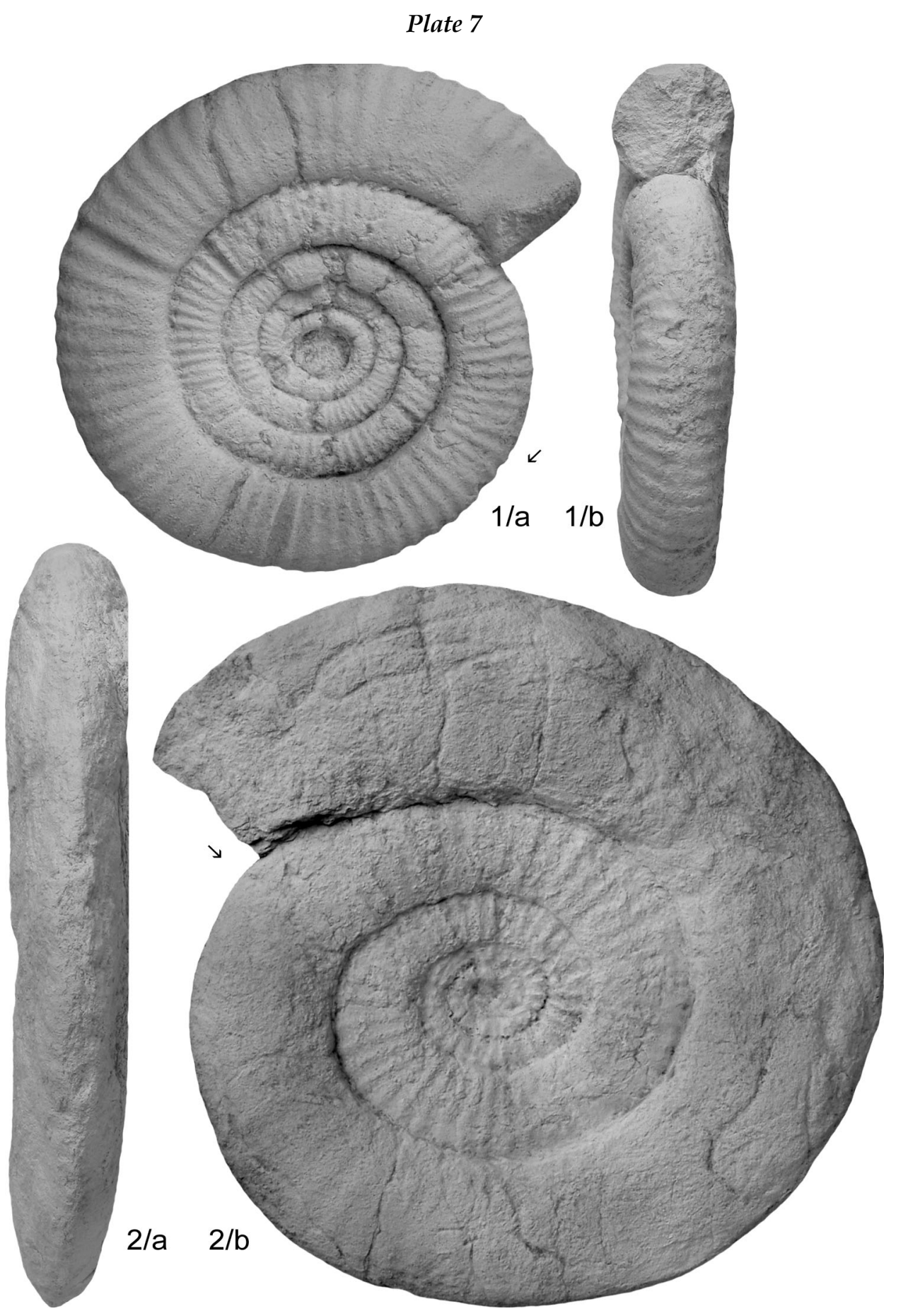

Central European Geology 53, 2010 


\section{References}

Arkell, W.J. 1957: Mesozoic Ammonoidea. - In: Moore, R.C. (Ed): Treatise on Invertebrate Paleontology, Part L, Mollusca 4, Cephalopoda, Ammonoidea. - Kansas University Press, Kansas and New York, pp. 80-471.

Arp, G. 2010: Ammonitenfauna und Stratigraphie des Grenzbereichs Jurensismergel/OpalinustonFormation bei Neumarkt i.d. Opf. (oberstes Toarcium, Fränkische Alb). - Zitteliana, A, 50, pp. 25-50.

Benecke, E.W. 1865: Über Trias und Jura in den Südalpen. - Geognostische-paläontologische Beiträge, 1, $205 \mathrm{p}$.

Benecke, E.W. 1905: Die Versteinerungen der Eisenerzformation von Deutsch-Lothringen und Luxemburg. - Abhandlungen zur Geologischen Specialkarte von Elsass-Lothringen, 6, pp. $1-598$.

Benshili, K. 1989: Lias-Dogger du Moyen-Atlas Plissé (Maroc), sédimentologie, biostratigraphie et évolution paléogéographique. - Documents des Laboratoires de Géologie de la Faculté des Sciences de Lyon, 106, pp. 1-285.

Branco, W. 1879: Der untere Dogger Deutsch-Lothringens. - Abhandlungen zur Geologischen Spezialkarte von Elsass-Lothringen, 2, pp. 1-160.

Buckman, S.S. 1887-1907: Monograph of the Ammonites of the "Inferior Oolite series". Palaeontographical Society, London, pp. 1-456, Supplement pp. 1- 210.

Callomon, J.H., R.B. Chandler 1994: Some early Middle Jurassic ammonites of Tethyan affinities from the Aalenian of southern England. - Palaeopelagos, Special Publication, 1, pp. 17-40.

Császár, G., A. Galácz, A. Vörös 1998: Jurassic of the Gerecse Mountains, Hungary: facies and Alpine analogies (in Hungarian). - Földtani Közlöny, 128/2-3, pp. 397-435.

Dezi, R., S. Ridolfi 1978: Fauna Ammonitica del Toarciano Superiore di Monte Carcatora (CingoliMarche). - Tip. Litocompagnucci, Macerata, 73 p.

Donovan, D.T., J.H. Callomon, M.K Howarth 1981: Classification of Jurassic Ammonitina. - In.: House, M.R., I.R. Senior (Eds): The Ammonoidea. Systematics Association Spec. Vol. 18, Acad. Press, London and New York, pp. 101-155.

Dumortier, E. 1874: Études paléontologiques sur les dépots jurassiques du Bassin du Rhone. - T. IV.: le Lias supérieur (ed. Savy, F), Paris, 252 p.

El Hammichi, F., K. Benshili, S. Elmi 2009: Les faunes d'Ammonites du Toarcien-Aalénien du Moyen Atlas sud-occidental (Maroc). - Revue de Paléobiologie, 27/2 (2008), pp. 429-447.

El Hariri, K., M.H. Henriques, D. Chafiki, L.V. Duarte, H. Ibouh 2006: Ammonites from Lias-Dogger of n'Zala (Central High Atlas, Morocco). - In: Abstracts of talks and posters presented during 7. International Congress on the Jurassic System, Session 4: Integrated Stratigraphy, Warsaw, Volumina Jurassica, 4, pp. 170-171.

Elmi, S., F. Atrops, C. Mangold 1974: Les Zones d'Ammonites du Domérien - Callovien de l'Algérie occidentale. - Documents des Laboratoires de Géologie de la Faculté des Sciences de Lyon, 61, pp. 1-83.

Elmi, S., R. Mouterde, R. Rocha, L. Rulleau 2007: Une succession de référence pour le Toarcien Moyen et Supérieur: les "Margas calcárias de Sao Giao" dans les environs de Cantanhede sousbassin nord lusitanien, Portugal). - Ciencias da Terra (UNL) 16, pp. 113-133.

Elmi, S., L. Rulleau, J. Gabilly, R. Mouterde 1997: Toarcien. - In: Cariou, E., P. Hantzpergue (Eds): Biostratigraphie du Jurassique ouest-européen et méditerranéen. - Bulletin du Centre des Recherches, Elf Explor. Prod. Mém. 17, Pau Cedex, pp. 25-36.

Fauré, PH. 2002: Le Lias des Pyrénées. - STRATA. Actes du Laboratoire de Géologie Sédimentaire et Paléontologie de l'Université Paul-Sabatier, Série II: Mémoires, 39, pp. 1-761.

Fauré, Ph., R. Cubaynes 1983: La sous-zone à Pleydellia celtica n. sp. (Dumortierinae, Ammonitina) nouvel élément biostratigraphique de la zone à Aalensis dans le Toarcien du Sud du Quercy (bordure Est du bassin d'Aquitaine). - Comptes Rendus de l'Académie des sciences, Série II, 297, pp. 681-686.

Fernández-López, S.R., M.H. Henriques, A. Linares, J. Sandoval, M.S. Ureta 1999a: Aalenian Tmetoceras (Ammonoidea) from Iberia. Taxonomy, Habitats and Evolution. - In: Olóriz, F, FJ. 
Rodríguez-Tovar (Eds): Advancing Research on Living and Fossil Cephalopods, Kluwer Academic/Plenum Publishers, New York, pp. 91-108.

Fernández-López, S.R., M.H. Henriques, A. Linares, J. Sandoval, M.S. Ureta 1999b: Aalenian Tmetoceras (Ammonoidea) from Iberia. Taphonomy and Palaeobiogeography. - In: Olóriz, F, FJ. Rodríguez-Tovar (Eds): Advancing Research on Living and Fossil Cephalopods, Kluwer Academic/Plenum Publishers, New York, pp. 395-417.

Gabilly, J. 1976: Évolution et systématique des Phymatoceratinae et des Grammoceratinae (Hildocerataceae, Ammonitina) de la région de Thouars, stratotype du Toarcien. - Mémoires de la Société géologique de France, 54, pp. 1-196.

Gabilly, J., R. Mouterde 1994: Dumortieria levesquei (d'Orbigny, 1844), - In: Fischer, J.-C. (Ed.) Révision Critique de la Paléontologie Francaise d'Alcide d'Orbigny, Masson, Paris, pp. 58-59.

Galácz, A., B. Géczy, A. Vörös 2007: Toarcian and Aalenian (Jurassic) ammonites and brachiopods from Monte Kumeta, Western Sicily. - Neues Jahrbuch für Geologie und Paläontologie [Abhandlungen], 245/3, pp. 341-352.

García-Gómez, R., A.P. Jiménez, A. Linares, P. Rivas, J. Sandoval 1994: The Toarcian-Aalenian boundary in the Betic Cordillera (Southern Spain). - Geobios, [M.S.] 17, pp. 211-222.

Géczy, B. 1967: Ammonoides Jurassiques de Csernye, Montagne Bakony, Hongrie, Part II. (excl. Hammatoceratidae). - Geologica Hungarica Series Palaeontologica, 35, pp. 1-413.

Géczy, B. 1968: Deformed Jurassic Ammonoids from Úrkút (Bakony Mountains, Transdanubia). Annales Universitatis Scientiarum Budapestinensis de Rolando Eötvös nominatae, Sectio Geologica, 11, pp. 117-132.

Géczy, B. 1975: The Lower Jurassic Ammonite faunas of the Southern Bakony (Transdanubia, Hungary). - Annales Universitatis Scientiarum Budapestinensis de Rolando Eötvös nominatae, Sectio Geologica, 17, pp. 181-191.

Géczy, B. 1984: Provincialism of Jurassic ammonites, examples from Hungarian faunas. - Acta Geologica Hungarica, 27/3-4, pp. 379-389.

Géczy, B. 1985: Toarcian Ammonite Zones in the Gerecse Mountains, Hungary. - In: Michelsen, O., A. Zeiss (Eds): International Symposium on Jurassic Stratigraphy (Erlangen) I, Copenhagen pp. 218-226.

Géczy, B., I. Szente 2007: Middle Toarcian Ammonitina from the Gerecse Mts, Hungary. - Acta Geologica Hungarica, 49/3, pp. 223-252.

Gemmellaro, G. 1886: Sul Dogger inferiore di Monte San Giuliano (Erice). - Giornale di Scienze Naturali ed Economiche, 17 (1885-1886), pp. 197-213.

Gérard, Ch., J. Bichelonne 1940: Les Ammonites Aaléniennes du minerai de fer de Lorraine. Mémoires de la Société Géologique de France, 42, pp. 1-60.

Goy, A., S. Ureta 1988: Ammonitina del Toarciense superior en la Sierra Norte de Mallorca (España). - Boletín de la Real Sociedad Española de Historia Natural. Sección geológica, 84/1-2, pp. $19-38$.

Goy, A. 2002: Genus Catulloceras Gemmellaro, 1886, p. 153, Catulloceras dumortieri (Thiolliere in Dumortier, 1874). - In: Revision of Jurassic ammonites of the Gemmellaro collections, Quaderni del Museo Geologico "G. G. Gemmellaro", (coord. Pavia, G. and Cresta, S.), Palermo, pp. $154-156$

Goy, A., G. Martínez, S. Ureta 1994: El Toarciense en la región de Pozazal-Reinosa (Cordillera Cantábrica, Espana). - Coloquios de Paleontologia, 46, pp. 93-126.

Haug, E. 1885: Beiträge zu einer Monographie der Ammonitengattung Harpoceras. - Neues Jahrbuch für Mineralogie, Geologie und Paläontologie, 3, pp. 585-722.

Haug, E. 1887: Ueber die "Polymorphidae", eine neue Ammonitenfamilie aus dem Lias. - Neues Jahrbuch für Mineralogie, Geologie und Palaeontologie [Jahrgang], 2, pp. 89-163.

Henriques, M.H. 1992: Biostratigrafia e Paleontologia (Ammonoidea) do Aaleniano em Portugal (Sector Setentrional da Bacia Lusitaniana) - Unpublished PhD Thesis., Universidade de Coimbra, I.N.I.C., 301 p.

Henriques, M.H. 2000: Biostratigraphie (Ammonoidea) du passage Lias-Dogger dans le Bassin Lusitanien: la coupe de S. Gião (Portugal). - STRATA. Actes du Laboratoire de Géologie Sédimentaire et Paléontologie de l'Université Paul-Sabatier, Série I, 10, pp. 31-35.

Central European Geology 53, 2010 
Henriques, M.H., S. Ureta 2002: Cotteswoldia limatula Buckman, 1902; Pleydellia aalensis (Zieten, 1830). - In: Revision of Jurassic ammonites of the Gemmellaro collections, Quaderni del Museo Geologico "G. G. Gemmellaro" (coord. Pavia, G. and Cresta, S.), Palermo, pp. 149-153.

Jakobs, G.K., P.L. Smith 1996: Latest Toarcian Ammonoids from the North American Cordillera. Palaeontology, 39/1, pp. 97-147.

Kovács, Z. 2009: Toarcian-Aalenian Hammatoceratinae (Ammonitina) from the Gerecse Mts (NE Transdanubian Range, Hungary). - Fragmenta Palaeontologica Hungarica, 27, pp. 1-72.

Kovács, Z. 2010: Paroniceratidae (Ammonitina) of the Toarcian from the Gerecse Mts (NE Transdanubian Range, Hungary). - Földtani Közlöny, 140/2, pp. 119-134.

Kovács, Z., B. Géczy 2008: Upper Toarcian-Middle Aalenian (Jurassic) Erycitinae Spath (Ammonitina) from the Gerecse Mts, Hungary. - Hantkeniana, 6, pp. 57-108.

Levi Setti, F. 1968: Ammoniti del genere Dumortieria nella serie toarciana del Passo del Furlo (Appennino Centrale). - Atti della Società Italiana di Scienze Naturali e del Museo Civico di Storia Naturale di Milano, 107/3-4, pp. 317-347.

Maubeuge, P.L. 1950: Nouvelles reserches stratigraphiques et paléontologiques sur l'Aalénien luxembourgeois. - Archives de la Section des Sciences naturelles, physiques et mathématiques de l'Institut Grand-Ducal de Luxembourg, 19, pp. 365-397.

Meneghini, J. 1867-1881: Monographie des fossiles du calcaire rouge ammonitique (Lias supérieur) de Lombardie et de l'Apennin Central. - In: Stoppani, A.: Paléontologie Lombarde, 4, Milan, pp. 1-242.

Metodiev, L. 1997: Toarcian and Aalenian ammonites in a part of the Western Stara Planina Mts, Bulgaria (taxonomy, stratigraphy). - Geologica Balcanica, 27/3-4, pp. 3-31.

Metodiev, L. 2008: The Ammonite zones of the Toarcian in Bulgaria - New evidence, subzonation and correlation with the standard zones and subzones in North-Western Europe. - Comptes rendus de l'Académie bulgare des Sciences, 61/1, pp. 87-132.

Myczynski, R. 2004: Toarcian, Aalenian and Early Bajocian (Jurassic) ammonite faunas and biostratigraphy in the Pieniny Klippen Belt and the Tatra Mts, West Carpathians. - Studia Geologica Polonica, 123, pp. 1-131.

Nutsubidze, K. 1966: Lower Jurassic fauna of Caucasus. - Geological Institute of Gruziya, Tbilisi, pp. 1-212. (In Russian.)

Ohmert, W. (von) 1993: Zur Entwicklung der Grammoceratinae - Leioceratinae an der Toarcium-/Aalenium-Grenze Südwestdeutschlands. - Geologische Blätter von Nordostbayern, 43/1-3, pp. 143-166.

Ohmert, W., C.H. Rolf 1994: The Aalenian boundaries at Wittnau (Oberrhein area, south west Germany). - In: Proceedings of 3rd International Meeting on Aalenian and Bajocian Stratigraphy, Miscellanea, 5, pp. 33-61, Servizio Geologico Nazionale, Roma.

d'Orbigny, A. 1842-1851: Paléontologie francaise, Terrains Jurassique I.: Céphalopodes, V. Masson, Paris, pp. 1-642.

Pallini G., S. Elmi, F. Gasparini 2005: Late Toarcian - Late Aalenian Ammonites Assemblage from Mt. Magaggiaro (Western Sicily, Italy). - Geologica Romana, 37 (2003-2004), pp. 1-66.

Pinna, G. 1968: Ammoniti del Lias Superiore (Toarciano) dell'Alpe Turati (Erba, Como). - Memorie della Società Italiana di Scienze Naturali e del Museo Civico di Storia Naturale di Milano, 17/1, pp. 1-69.

Pinna, G. 1969: Revisione delle ammoniti figurate da Giuseppe Meneghini nelle Tav. 1-22 della "Monographie des fossiles du calcaire rouge ammonitique" (1867-1881). - Memorie della Società Italiana di Scienze Naturali e del Museo Civico di Storia Naturale di Milano, 18/1, pp. $1-16$.

Prinz, Gy. 1904: Die Fauna der älteren Jurabildungen im nordöstlichen Bakony. - Mitteilungen aus dem Jahrbuche der kgl. Ungarischen Geologischen Anstalt, 15 (1904-1907), pp. 1-142.

Prinz, Gy. 1906: Dumortierien von Piszke. - Földtani Közlöny, 36, pp. 161-162.

Quenstedt, F. A. 1885: Die Ammoniten des Schwäbischen Jura I., Der Schwarze Jura (Lias), Stuttgart, pp. 1-440. 
Renz, C. 1910: Stratigraphische Untersuchungen in griechischen Mesozoikum und Paläozoikum. Jahrbuch der k.k. Geologischen Reichsanstalt, 60, pp. 421-636.

Rostovtsev, K.O. 1965: Upper Toarcian ammonites of the Western Caucasus. - Transactions of the Krasnodar Branch of the All-Soviet Oil-and-gas Scientific Institute, 16, Leningrad, pp. 50-86. (In Russian.)

Rulleau, L. 1995: Les Graphoceratidae du Toarcien superieur et de l'Aalenien de la region lyonnaise. - Section Géologie-Paléontologie du C.E. des Ciments Lafarge, Lozanne, 12 p.

Rulleau, L. 2007: Biostratigraphie et Paleontologie du Lias superieur et du Dogger de la region lyonnaise, Tome 1. - Section Géologie et Paléontologie du Comité d'Enterprise Lafarge Ciments, Lozanne, $382 \mathrm{p}$.

Rulleau, L., S. Elmi, B. Thévenard 2001: Géologie et Paléontologie des dépots ferrugineux du Toarcien et de l'Aalénien aux environs de Lyon. - Documents des Laboratoires de Géologie de la Faculté des Sciences de Lyon, 154, pp. 1-153.

Rulleau, L., R. Mouterde 1997: Les genres Catulloceras Gemmellaro et Tmetoceras Buckman, systématique, stratigraphie et paléobiogéographie. - Cahiers de l'Université Catholique de Lyon, 10, pp. 79-91.

Sandoval, J. 2002: Subfamily Tmetoceratinae Spath, 1936. - In: Revision of Jurassic ammonites of the Gemmellaro collections, Quaderni del Museo Geologico "G. G. Gemmellaro" (coord. Pavia, G. and Cresta, S.), Palermo, pp. 160-166.

Schindewolf, O.H. 1964: Studien zur Stammesgeschichte der Ammoniten - Abhandlungen der Mathematisch-Naturwissenschaftlichen Klasse (Jahrgang), 1963/6/3, pp. 289-432.

Schlegelmilch, R. 1976: Die Ammoniten des süddeutschen Lias. - G. Fischer Verlag, Stuttgart - New York, $212 \mathrm{p}$.

Schulbert, CH. 2001: Die Ammonitenfauna und Stratigraphie der Tongrube Mistelgau bei Bayreuth (Oberfranken). - Beihefte zu den Berichten der Naturwissenschaftlichen Gesellschaft Bayreuth, $4,83 \mathrm{p}$.

Schweigert, G. 1996: Seltene Ammoniten aus dem Opalinuston (Unter-Aalenium) des Schwäbischen Jura Baden-Württemberg). - Stuttgarter Beiträge zur Naturkunde (B), 244, pp. 1-17.

Seyed-Emami, K., FT. Fürsich, M. Wilmsen, G. Schairer, M.R. Majidifard 2005: Toarcian and Aalenian (Jurassic) ammonites from the Shemshak Formation of the Jajarm area (eastern Alborz, Iran). Paläontologische Zeitschrift, 79/3, pp. 349-369.

Seyed-Emami, K., FT. Fürsich, M. Wilmsen, M.R. Majidifard, A. Shekarifard 2008: Lower and Middle Jurassic ammonoids of the Shemshak Group in Alborz, Iran and their palaeobiogeographical and biostratigraphical importance. - Acta Palaeontologica Polonica, 53/2, pp. 237-260.

Seyed-Emami, K., M.H. Nabavi 1985: Dumortieria und Pleydellia (Ammonoidea) aus der ShemshakFormation (Obertrias - Mittlerer Jura) östlich von Shahmirzad (SE Alborz, Iran). - Neues Jahrbuch für Geologie und Paläontologie (Abhandlungen), 170/2, pp. 243-272.

Spath, L.F. 1936: On Bajocian Ammonites and Belemnites from Eastern Persia (Iran). Palaeontologia Indica [n. s.], 22/3, pp. 1-21.

Staff, H. (von) 1906: Beiträge zur Stratigraphie und Tektonik des Gerecse-gebirges. - Mitteilungen aus dem Jahrbuche der kgl. Ungarischen Geologischen Anstalt, 15 (1904-1907), pp. 183-235.

Topchishvili, M., T. Lominadze, I. Tsereteli, V. Todria, G. Nadareishvili 2006: Stratigraphy of the Jurassic deposits of Georgia. - Georgian Academy of Sciences A. Janelidze Geological Institute Proceedings (N.S.), 122, pp. 1-453.

Venturi, F, M. Bilotta 2008: New data and hypotheses on early Jurassic ammonite phylogeny. Revue de Paléobiologie, 27/2, pp. 859-901.

Venturi, F, R. Ferri 2001: Ammoniti Liassici dell'Appennino Centrale. - Tibergraph, Citta di Castello, p. 268.

Venturi, F, G. Rea, G. Silvestrini, M. Bilotta 2010: Ammonites. A geological journey around the Apennine Mountains. Porzi, Perugia, $367 \mathrm{p}$.

Zieten, C.H. (von) 1830-1833: Die Versteinerungen Württembergs. - Stuttgart, 102 p. 